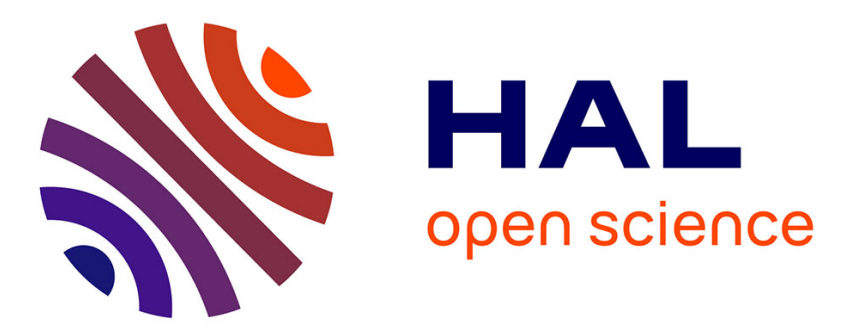

\title{
Assessing submarine groundwater discharge (SGD) and nitrate fluxes in highly heterogeneous coastal karst aquifers: Challenges and solutions
}

Daniel Montiel, Natasha Dimova, Bartolome Andreo, Jorge Prieto, Jordi Garcia-Orellanac, Valenti Rodellas

\section{To cite this version:}

Daniel Montiel, Natasha Dimova, Bartolome Andreo, Jorge Prieto, Jordi Garcia-Orellanac, et al.. Assessing submarine groundwater discharge (SGD) and nitrate fluxes in highly heterogeneous coastal karst aquifers: Challenges and solutions. Journal of Hydrology, 2018, 557, pp.222-242. 10.1016/j.jhydrol.2017.12.036 . hal-01765568

\section{HAL Id: hal-01765568 \\ https://hal.science/hal-01765568}

Submitted on 22 Jun 2018

HAL is a multi-disciplinary open access archive for the deposit and dissemination of scientific research documents, whether they are published or not. The documents may come from teaching and research institutions in France or abroad, or from public or private research centers.
L'archive ouverte pluridisciplinaire HAL, est destinée au dépôt et à la diffusion de documents scientifiques de niveau recherche, publiés ou non, émanant des établissements d'enseignement et de recherche français ou étrangers, des laboratoires publics ou privés. 
1 Assessing submarine groundwater discharge (SGD) and nitrate fluxes in

2 highly heterogeneous coastal karst aquifers: challenges and solutions

3

4 Daniel Montiel ${ }^{1 *}$, Natasha Dimova ${ }^{1}$, Bartolomé Andreo ${ }^{2}$, Jorge Prieto ${ }^{2}$, Jordi García-

5 Orellana ${ }^{3,4}$, Valentí Rodellas ${ }^{4,5}$

6

7

$8 \quad{ }^{1}$ Department of Geological Sciences, University of Alabama, 35487 Tuscaloosa, USA

$9 \quad{ }^{2}$ Center of Hydrogeology of the University of Malaga (CEHIUMA), 29590 Malaga, Spain

$10{ }^{3}$ Institut de Ciència i Tecnologia Ambientals (ICTA) Universitat Autònoma de Barcelona,

1108193 Bellaterra, Catalunya, Spain

$12{ }^{4}$ Departament de Física, Universitat Autònoma de Barcelona, 08193 Bellaterra, Catalunya,

13 Spain.

$14{ }^{5}$ CEREGE, Aix-Marseille Université, CNRS, IRD, Coll France, 13545 Aix-en-Provence, 15 France

16

17

18 Corresponding author: Daniel Montiel

19 Email address: dmontielmartin@crimson.ua.edu

$20 \quad$ Tel.: 0012058614772 
21 Postal address: Department of Geological Sciences, University of Alabama, 35487

22 Tuscaloosa, USA

24 Email address of coauthors:

$25 \quad$ Natasha Dimova: ntdimova@ua.edu

26 Bartolomé Andreo: andreo@uma.es

27 Jorge Prieto: prieto@uma.es

28 Jordi García-Orellana: jordi.garcia@uab.cat

$29 \quad$ Valentí Rodellas: rodellas@cerege.fr

31 Abstract

32 Groundwater discharge in coastal karst aquifers worldwide represents a substantial

33 part of the water budget and is a main pathway for nutrient transport to the sea.

34 Groundwater discharge to the sea manifests under different forms, making its assessment

35 very challenging particularly in highly heterogeneous coastal systems karst systems. In this

36 study, we present a methodology approach to identify and quantify four forms of

37 groundwater discharge in a mixed lithology system in southern Spain (Maro-Cerro Gordo)

38 that includes an ecologically protected coastal area comprised of karstic marble. We found

39 that groundwater discharge to the sea occurs via: (1) groundwater-fed creeks, (2) coastal

40 springs, (3) diffuse groundwater seepage through seabed sediments, and (4) submarine

41 springs. We used a multi-method approach combining tracer techniques (salinity, ${ }^{224} \mathrm{Ra}$,

42 and ${ }^{222} \mathrm{Rn}$ ) and direct measurements (seepage meters and flowmeters) to evaluate the

43 discharge. Groundwater discharge via submarine springs was the most difficult to assess

44 due to their depth (up to $15 \mathrm{~m}$ ) and extensive development of the springs conduits. We 
45 determined that the total groundwater discharge over the $16 \mathrm{~km}$ of shoreline of the study 46 area was at least $11 \pm 3 \times 10^{3} \mathrm{~m}^{3} \mathrm{~d}^{-1}$ for the four types of discharge assessed. Groundwater47 derived nitrate $\left(\mathrm{NO}_{3}{ }^{-}\right.$) fluxes to coastal waters over $\sim 3 \mathrm{~km}$ (or $20 \%$ ) in a highly populated 48 and farmed section of Maro-Cerro Gordo was $641 \pm 166 \mathrm{~mol} \mathrm{~d}^{-1}$, or $\sim 75 \%$ of the total $\mathrm{NO}_{3}{ }^{-}$ 49 loading in the study area. We demonstrate in this study that a multi-method approach must 50 be applied to assess all forms of SGD and derived nutrient fluxes to the sea in highly 51 heterogeneous karst aquifer systems.

52

53 Keywords: Coastal karst aquifers, submarine groundwater discharge, nitrate fluxes, multi54 method approach.

55 


\section{Introduction}

Coastal karst aquifers are $46 \%$ of the Mediterranean coastline, and play a key role in regional socioeconomic, providing residents with essential water resources (Fleury et al., 2007; Bakalowicz, 2015; Arfib and Charlier, 2016; Trezzi et al., 2017). Groundwater is often the only available source as Mediterranean precipitation is scarce and sporadic, and often limited runoff due to efficient infiltration and percolation through the karst aquifers (McCormack et al., 2014). Typically, karstified carbonate aquifers are comprised of a complex set of fractures, conduits, and cavities generating high spatial and temporal heterogeneity in groundwater flow (Worthington, 1999; Bakalowicz et al., 2005; Barberá and Andreo, 2015). This in turn results in challenging water resources management and attempts to develop water budgets and numerical models describing karst systems often fail or result in estimates with large uncertainties (Butscher and Huggenberger, 2007; Martínez -Santos and Andreu, 2010; Rapaglia et al., 2015). When a karst system is hydraulically connected to the sea, a significant part of groundwater can flow directly to the sea in different forms (Stringfield and Legrand, 1971; Pinault et al., 2004; Custodio, 2010). Groundwater discharge to the sea can occur via submarine springs (Fleury et al., 2007; Bakalowicz et al., 2008; Dimova et al., 2011) or subaerial coastal springs near the shoreline (Aunay et al., 2003; Mejías et al., 2008; García-Solsona et al., 2010) depending on the geologic structure (Bonacci and Roje-Bonacci, 1997; Benac et al., 2003; Stamatis et al., 2011). Conduits and fractures buried under seabed sediments near the shoreline can also produce diffuse groundwater seepage (e.g. Tovar-Sánchez et al., 2014; Rodellas et al., 2012). Conversely, impervious strata can create enough hydraulic pressure for inland springs whose runoff flows to the sea as groundwater-fed creeks without experiencing infiltration (e.g. Yobbi, 1992; Katz et al., 2009). In this work, we will use the widely accepted term submarine 
79

80

81

82

groundwater discharge (SGD) for the submerged forms of groundwater discharge to the sea as defined by Burnett et al. (2003) and Moore (2010).

Groundwater discharge of unconsolidated sedimentary coastal aquifers has been considered an insignificant component in water and nutrient budgets, mostly due to its relatively small $(<10 \%)$ volumetric contribution compared to surface water (Burnett and Dulaiova, 2003; Moore 2010). However, in karst systems with limited runoff, SGD is a major component of the coastal aquifer water and nutrient budget. Where excess of nutrients are delivered in coastal systems, these produce ecological perturbations such as harmful algae blooms (e.g. Hallegraeff, 1993; Smith and Swarzenski, 2012), and seagrass habitat modification (e.g.Valiela et al., 1992) to mention a few.

Coastal karst SGD can have very different composition due to the wide range of groundwater residence time and complex pathways of the discharging waters (Weinstein et al., 2011; Tovar-Sánchez et al., 2014; Trezzi et al., 2016). It is therefore necessary to apply a multimethod approach to adequately identify and assess all forms of groundwater discharge when they coexist.

A number of techniques have been developed to identify and estimate groundwater discharge to coastal areas under different climatic conditions and geologic settings. For instance, naturally occurring radon and radium isotopes are effective groundwater tracers of SGD (e.g. Cable et al., 1996; García-Solsona et al., 2010; Rodellas et al., 2015; Dimova et al., 2015) as they are chemically conservative and are typically a few orders of magnitude higher concentrations in groundwater than surface waters, allowing for easy detection in receiving coastal waters (Burnett et al., 2003). Furthermore, mass balance determination of radium and radon excess in near-shore surface quantifies the magnitude of groundwater fluxes (Cable et al., 1996; Wong et al., 2013; 
102 Tovar-Sánchez et al., 2014). Specifically, ${ }^{222} \mathrm{Rn}\left(\mathrm{t}_{1 / 2}=3.8 \mathrm{~d}\right)$ and ${ }^{224} \mathrm{Ra}\left(\mathrm{t}_{1 / 2}=3.6 \mathrm{~d}\right)$ which have 103 relatively short half-lives, and in the time-scale range of typical coastal mixing processes can be 104 used in combination to assess SGD (Moore, 1996; Cable et al., 1996; Burnett and Dulaiova, 105 2003).

Alternatively, in areas of faster groundwater flow regimes (e.g. karst and volcanic 107 systems), salinity (e.g. Knee et al., 2010; Stieglitz et al., 2010; García -Solsona et al., 2010; 108 Dimova et al., 2011) and thermal anomalies along the shoreline at the points of discharge are 109 proven to be good indicators of SGD (e.g. Pluhowski, 1972; Johnson et al., 2008; Peterson et al., 110 2009; Mejías et al., 2012; Tamborski et al., 2015). In areas where permeable sediments are 111 present, direct measurements of SGD using seepage meters are used in parallel with radiotracer 112 techniques (Lee, 1977; Burnett et al., 2006; Sadat-Noori et al., 2015).

The mixed lithology Maro-Cerro Gordo coastal area is an example where identifying and 114 quantifying all components of groundwater discharge are critical to building a comprehensive 115 water budget that addresses adequately the existing economic and ecological demands of the 116 adjacent coastal communities and ecosystems. Land use includes intensive agriculture with 1.3 $117 \mathrm{~km}^{2}$ of greenhouses and additional surface tropical crops, in combination with accelerating 118 tourism in the area during the past decades. These land uses are increasingly satisfied by 119 groundwater extractions, in this case from the Sierra Almijara-Alberquillas Aquifer (Andreo and 120 Carrasco, 1993), a highly fissured and karstified marble formation within the study site.

121 In order to assess the severity and impact of the increasing groundwater abstractions, 122 water managers require a comprehensive water budget for the area. The current water budget 123 based on a mass balance approach indicates total fresh water of $50 \times 10^{6} \mathrm{~m}^{3} \mathrm{y}^{-1}$ for the Sierra 124 Almijara-Alberquillas Aquifer (Castillo et al., 2001). This budget was suggested to be comprised 
125 of: (1) inland springs and intermittent creeks $\left(32 \times 10^{6} \mathrm{~m}^{3} \mathrm{y}^{-1}\right)$, (2) extraction for irrigation and 126 consumption purposes $\left(12 \times 10^{6} \mathrm{~m}^{3} \mathrm{y}^{-1}\right)$, (3) water transfer to the Neogene-Quaternary coastal 127 formations, and the remaining part to (4) groundwater discharge to the sea $\left(6 \times 10^{6} \mathrm{~m}^{3} \mathrm{y}^{-1}\right)$. A 128 more recent water mass balance budget using the APLIS (A = altitude, $\mathrm{P}=$ slope, $\mathrm{L}=$ lithology, I 129 = infiltration landforms, S = soil type) method (Andreo et al., 2008) included an infiltration 130 coefficient of $40-45 \%$ and confirmed that the total budget of the Sierra Almijara-Alberquillas 131 Aquifer is $50 \times 10^{6} \mathrm{~m}^{3} \mathrm{y}^{-1}$ for $2003-2005$, which were notably dry years (Pérez-Ramos and 132 Andreo, 2007). This assessment based on 2003-2005 data found a slightly higher natural 133 drainage through springs $\left(38 \times 10^{6} \mathrm{~m}^{3} \mathrm{y}^{-1}\right)$ and extraction $\left(15 \times 10^{6} \mathrm{~m}^{3} \mathrm{y}^{-1}\right)$ compared to the 134 estimate by Castillo et al. (2001), suggesting that groundwater discharge is negligible. However, 135 more recently SGD was found to be significant at $1 \times 10^{6} \mathrm{~m}^{3} \mathrm{y}^{-1}$ in Maro-Cerro Gordo using a 136 combination of GIS-based approach, hydrometeorological methods, and preliminary ${ }^{224} \mathrm{Ra}$ 137 evaluations (Andreo et al., 2017).

138 In this study, we performed a comprehensive assessment of the total groundwater 139 discharge to the sea in the Maro-Cerro Gordo area through the application of a set of methods 140 selective to each form of discharge. We used a combination of radiotracers $\left({ }^{222} \mathrm{Rn}\right.$ and $\left.{ }^{224} \mathrm{Ra}\right)$ and 141 salinity mass balances, seepage meter measurements, and flowmeter measurements to: (1) 142 identify point discharges to the sea; and (2) quantify the total groundwater dicharge from the 143 Sierra Almijara-Alberquillas Aquifer to adjacent coastal waters. We further (3) estimated 144 groundwater-derived nitrate $\left(\mathrm{NO}_{3}{ }^{-}\right)$fluxes to the coastal waters of Maro-Cerro Gordo and 145 compared these $\mathrm{NO}_{3}{ }^{-}$fluxes in an ecologically protected area (with low anthropogenic activities) 146 to unprotected zones (with intense agriculture and overpopulation). The sampling campaigns 147 were conducted during base flow conditions to provide a conservative estimate of the total 
148 149

groundwater discharge to the sea and nitrate fluxes of the Sierra Almijara-Alberquillas Aquifer and Maro-Cerro Gordo coastal area. Finally, (4) we compared the applicability of each method to assess the forms of groundwater discharge and made recommendations for applying this approach to other karst aquifer systems worldwide.

\section{Study site and hydrogeological settings}

The study site, Maro-Cerro Gordo, is located along the coastal fringe between Nerja and La Herradura in the easternmost section of the Malaga Province and part of the western Granada Province (Southern Spain) along $16 \mathrm{~km}$ of shoreline (Fig. 1). Approximately $80 \%$ of the study area is within the environmentally protected Maro-Cerro Gordo Natural Area, which comprises $3.58 \mathrm{~km}^{2}$ and $14.31 \mathrm{~km}^{2}$ of terrestrial and marine surface respectively. The area is characterized by a typical Mediterranean climate with average annual precipitation of $500 \mathrm{~mm} \mathrm{y}^{-1}$ occurring almost entirely during fall and winter (Andreo and Carrasco, 1993). We have divided the area in three sections based on their predominant lithology and associated forms of discharge. From east to west these are: (1) karst section, which includes the Cerro Gordo cape from Cañuelo Beach to La Herradura; (2) schist section, confined between El Cañuelo Beach and Maro Beach; and (3) conglomerate section, which comprises the area between Maro Beach and Nerja (city) (Fig. 1).

Figure 1: Study site location and geological map showing water table contour lines (from Pérez-Ramos and Andreo, 2007), groundwater flow direction, important wells and piezometers, sampling points, and terrestrial springs. Groundwater discharge to the sea (TGD) is represented in purple and is based on this study. Coastal springs are represented as CS, groundwater-fed creeks as GC, diffuse groundwater seepage as GS, and submarine springs as SS. The study area is divided in 
three sections: conglomerate section, schist section, and karst section. The distribution of seagrass beds are based on Bañares-España et al. (2002), and Aranda and Otero (2014).

\subsection{Alberquillas Aquifer Unit}

The main aquifer formation in the study area is the Alberquillas Aquifer Unit, a telogenetic karst formation that underlines the southeast sector of the Sierra Almijara Aquifer unit and is comprised of highly fissured and karstified Triassic marble (Andreo and Carrasco, 1993). The lithology varies from dolomitic to calcitic marble over the $600 \mathrm{~m}$ maximum thickness from basement to the surface (Andreo et al., 1993). In general, the primary porosity of this unit is negligible and the degree of karstification is locally higher in the lower portion, with the exception of Nerja Cave, which is a $3 \times 10^{5} \mathrm{~m}^{3}$ cavity located $158 \mathrm{~m}$ above sea level and 930 m from the shoreline (Durán, 1996; Andreo et al., 1993; Jordá et al., 2011).

The Alberquillas Aquifer Unit exhibits an elongated shape towards the southeast and a total surface of $60 \mathrm{~km}^{2}$, and is directly in contact with the Mediterranean Sea only along the karst section (Fig. 1). The two aquifer units (Alberquillas and Almijara Aquifer units) are hydraulically connected, constituting the Sierra Almijara-Alberquillas Aquifer $\left(142 \mathrm{~km}^{2}\right)$, which recharges from local precipitation (Carrasco et al., 1998). Conceptual hydrogeological models developed for the Sierra Almijara-Alberquillas Aquifer suggest that groundwater generally flows from north to south, and SGD occurs mainly in eastern Cerro Gordo (Andreo and Carrasco 1993; Carrasco et al., 1998; Pérez-Ramos and Andreo, 2007).

The first attempt to locate SGD in Maro-Cerro Gordo was performed by Espejo et al. (1988) via airborne infrared thermal (IRT) remote sensing. Two thermal anomalies were detected during this survey, one in the Maro area (conglomerate section), and one in the vicinity of Cerro 
194 Gordo and Cantarrijan (karst section); these were also confirmed by lower surface seawater 195 salinity (Espejo et al., 1988).

A cluster of three submarine caves with active springs (Cantarrijan Caves) were 197 identified at water depths of about $7 \mathrm{~m}$ near the Cantarrijan Beach (Fig. 1) during SCUBA diving explorations in the karst section during this study. The vents of these springs are located at the 199 same depth and only $2-3 \mathrm{~m}$ away from each other. Thus, in our assessments the flux of these 200 three springs was treated as a single discharge point. We identified the vents of two additional 201 submarine springs at water depths of $12 \mathrm{~m}$ (Palomas Cave) and $15 \mathrm{~m}$ (Sifon Cave) in anchialine 202 caves with up to $10 \mathrm{~m}$ of horizontal development (Fig. 1). These caves, together with the three small Cantarrijan Cave springs, represent the deep SGD of Sierra Almijara-Alberquillas Aquifer 204 in the karst section. From SCUBA diving observations, we found that all three discharge points 205 are related to highly-developed karstic conduits at depth. We found during this study that they 206 were active even during droughts (Fig. 2), showing base flow conditions of Sierra Almijara207 Alberquillas Aquifer water budget drainage. most of its extension and is tectonically in contact through a set of faults (Andreo et al., 1993).

211 Metamorphosed during the Alpine Orogeny it presents a maximum thickness of $500 \mathrm{~m}$ and very 212 low hydraulic conductivity (Andreo et al., 1993). Outcrops of the schist formation can be found 213 almost along the entire schist section (Fig. 1). The schist formation serves as a hydrogeological 214 barrier for SGD in this area (Andreo and Carrasco, 1993), and groundwater discharge to the sea 215 in this section manifests as four small-size creeks and one coastal spring. The four creeks 216 include: Tierras Nuevas Creek which emanates from a soil layer on the schist formation; the 
217 Colmenarejos Creek which was dry over the sampling campaigns; Miel Creek which is of

218 particular interest as it is solely fed by permanently discharging springs located along the Sierra 219 Almijara-Alberquillas Aquifer in the sea (Andreo and Carrasco, 1993). The Maro Stream was 220 observed to be produced by irrigation excess from abundant agriculture located nearby.

222 Beach at the contact between the highly permeable Alberquillas Aquifer Unit karstic marble and impermeable schist, was found to have a perennial flow regime.

\subsection{Conglomerate, breccia, and travertine formations}

Pliocene conglomerate and breccia deposits with a maximum thickness of $60 \mathrm{~m}$, form $90 \%$ of the conglomerate section of the study area, representing the second most important

227 permeable formation in the study site (Fourniguet, 1975; Andreo et al., 1993; Guerra-Merchán and Serrano, 1993). This formation is comprised of marble fragments cemented by a red matrix, 229 showing signs of dissolution in the upper portion due to its calcite composition. Its hydraulic conductivity permits limited groundwater flow mainly due to primary porosity and the slight presence of fractures (Andreo and Carrasco, 1993). In the coastline comprised of this formation, 232 groundwater discharge can be identified visually as two coastal springs, the Doncellas and Barranco Maro Spring and the groundwater-fed creek (Caleta Creek) which originates from a

234 spring located near the town of Maro (Fig. 1). On the easternmost sector of the conglomerate 235 section, south from the town of Maro, a $30 \mathrm{~m}$ thick highly porous and permeable quaternary 236 travertine is present in direct contact with the sea at Maro Cliff to the south (Jordá, 1988). The 237 two small coastal springs of Huerto Romero and Maro Beach are present in this formation along with the intermittent groundwater-fed creek of Maro Creek. We have observed that excess water

239 from the Maro Spring located approximately $1 \mathrm{~km}$ to the north of Maro Cliff, flows as Maro 
240 Creek and discharges to the sea from the travertine cliff as a waterfall that is intermittently active

241 depending on irrigation times. The Maro Sprig is well-known and it was included in the Sierra

242 Almijara-Alberquillas Aquifer water budget, and it is utilized for drinking and irrigation

243 purposes (Liñán et al., 2000). The Sanguino Creek remained dry throughout this study.

Figure 2: Average monthly precipitation and sea level change during 2010, 215, and 2016. Error bars show the monthly rainfall variability during this study. In December of 2015 slight precipitation occurred only during the first week, however, abundant rainfall took place during September-November. Sea level showed lower values during January-May and higher during August-December. Sampling campaigns were conducted during May-July (dry periods) and December (wet periods).

3 Methods

Water fluxes to the sea from karstic submarine springs were quantified using (1) ${ }^{224} \mathrm{Ra}$

254 and (2) salinity mass balances, groundwater seepage was quantified using both (3) a ${ }^{222} \mathrm{Rn}$ box 255 model mass balance and (4) seepage meter deployments in the locations where radon anomalies 256 were observed. Subaerial groundwater discharge from coastal springs and groundwater-fed 257 creeks was measured directly using a flowmeter (5).

\subsection{Tracer techniques}

\subsection{1 ${ }^{224}$ Ra distribution and submarine springs discharge assessment}

A total of 38 discreet ${ }^{224}$ Ra samples of $60 \mathrm{~L}$ each were collected in September of 2006 and 2010 to survey the schist and karst sections (Fig. 1). All seawater samples were collected at a 
264 obtained using a submersible pump, and were later passed through a PVC column filled with 265 about $25 \mathrm{~g}$ of $\mathrm{MnO}_{2}$-coated-fibers (Mn-fibers) at a flow rate of approximately $1 \mathrm{~L} \mathrm{~min}^{-1}$ to allow 266 for a quantitative absorption of ${ }^{224}$ Ra (Moore, 1976; 2008). Mn-fibers were then transferred to 267 the lab, rinsed with Ra-free water, and partially dried (Sun and Torgersen, 1998). Activities 268 of ${ }^{224} \mathrm{Ra}$ were measured using a Radium Delayed Coincidence Counter (RaDeCC) system 269 (Moore and Arnold, 1996; García-Solsona et al., 2008). The Mn-fibers were counted twice, with 270 the first time immediately after collection to assess the total ${ }^{224} \mathrm{Ra}$ in the water, and a second time 271 after a month to evaluate the supported ${ }^{224} \mathrm{Ra}$ in equilibrium with ${ }^{228} \mathrm{Th}$. The excess of ${ }^{224} \mathrm{Ra}$ was 272 used to construct a ${ }^{224} \mathrm{Ra}$ mass balance following Charette et al. (2001), which assumes that 273 the ${ }^{224} \mathrm{Ra}$ excess in coastal waters is the result of groundwater inputs (Eq. 1). This approach was 274 applied to assess water fluxes $\left(F_{S G D}, \mathrm{~m}^{3} \mathrm{~d}^{-1}\right)$ originated from the three submarine springs present 275 in the karst section of the study site (Fig 1):

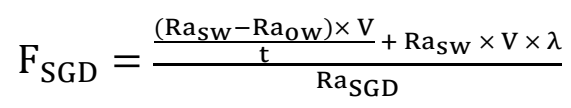

277 where $R a_{s w}$ is the ${ }^{224} \mathrm{Ra}$ activity in coastal waters, i.e. the surface water end-member $\left(\mathrm{dpm} \mathrm{m}^{-3}\right)$; $278 R a_{o w}$ is the offshore ${ }^{224} \mathrm{Ra}$ activity in open waters ( $\mathrm{dpm} \mathrm{m}^{-3}$ ); $R a_{S G D}$ is the activity of the 279 groundwater end-member $\left(\mathrm{dpm} \mathrm{m}^{-3}\right) ; t$ is the coastal water residence time $(\mathrm{d})$; $V$ is the volume $280\left(\mathrm{~m}^{3}\right)$ of coastal water affected by each submarine spring (SGD plume; and $\lambda$ is the ${ }^{224} \mathrm{Ra}$ decay 281 constant $\left(0.1894 \mathrm{~d}^{-1}\right)$.

282 Because this area is greatly exposed to prevailing west winds, large waves, and intensive 283 mixing, we assumed that the residence time $(t)$ of the water in this high energy coastline must be 284 no more than one day. Thus, we used the one-day value in our mass balance model. The volume 285 affected by SGD ( $V$ ) was constrained using the surface area of the salinity anomaly created by 286 the spring plume and corresponding water depths, obtained from the Andalusia Council of 
287 Environment bathymetry database: http://www.juntadeandalucia.es/medioambiente/site/rediam.

288 To obtain the ${ }^{224}$ Ra activity $\left(R a_{s w}\right)$ surface water end-member representative of the whole water 289 column, average values of water samples collected from the surface and at the depth of the 290 spring discharge were used.

\subsubsection{Salinity anomalies and submarine spring discharge evaluation}

To identify and quantify submarine springs discharge following the 1-meter isobath 293 parallel to the shoreline, three salinity boat surveys were performed in May, July, and December 294 of 2015 along the entire stretch of the studied coastline. Electrical conductivity (EC) and 295 temperature $\left(T,{ }^{\circ} \mathrm{C}\right)$ were measured continuously at a constant depth of $0.3 \mathrm{~m}$ with accuracies of $296 \pm 20 \mu \mathrm{S} \mathrm{cm}^{-1}$ and $\pm 0.1^{\circ} \mathrm{C}$ by towing a conductivity-temperature-depth sensor (CTD, Solinst ${ }^{\circledR}$ ) 297 from boat at a speed of about $2 \mathrm{~km} \mathrm{~h}^{-1}$. Seawater salinity values were obtained from EC using the 298 conversion method 2520B (Standard Methods for the Examination of Water and Wastewater, 299 APHA, 1999). Data were recorded in 2 min intervals concurrently with precise GPS boat 300 positioning recorded in 30-sec intervals (Garmin Etrex ${ }^{\circledR} 20 \mathrm{x}$ ) with an accuracy of $\pm 3 \mathrm{~m}$. 301 Electrical conductivity and temperature of groundwater samples were measured using a Pro2030 302 (YSI Inc.) handheld instrument with accuracies of $\pm 1 \mu \mathrm{S} \mathrm{cm}{ }^{-1}$, and $\pm 0.3^{\circ} \mathrm{C}$. Before sampling, 303 the CTD sensor and handheld instrument (YSI) were calibrated using two conductivity solutions $304\left(\right.$ Oakton $\left.^{\circledR}\right): 1413 \mu \mathrm{S} \mathrm{cm}{ }^{-1}$ and $12,880 \mu \mathrm{S} \mathrm{cm}^{-1}$, measured at $25^{\circ} \mathrm{C}$. Temperature correction for EC 305 was automatically performed using linear compensations of $2 \%{ }^{\circ} \mathrm{C}^{-1}$ and $1.91 \%{ }^{\circ} \mathrm{C}^{-1}$ for the CTD 306 sensor and the handheld instrument respectively.

To compare data points from all surveys and identify consistent spatial salinity variations

308 (i.e. permanent groundwater fluxes) independent of seasonal fluctuations, salinity values from 309 each survey were normalized based on their total average. Salinity anomalies were defined as 
310 positive when salinity is higher than average and negative when it is lower than the average 311 value.

A salinity mass balance based on the salinity anomalies generated by submarine springs

313 inputs was constructed to determine groundwater fluxes $\left(F_{S G D}, \mathrm{~m}^{3} \mathrm{~d}^{-1}\right)$ in the karst section using 314 Eq. 2 and following Crusius et al. (2005) and Knee et al. (2010). To calculate the fresh water 315 fraction of the spring discharge, we used the approach described in Knee et al. (2010), which 316 indirectly defines the groundwater salinity end-member $\left(\mathrm{Sal}_{S G D}\right)$ to be zero (Eq. 2):

$$
\mathrm{F}_{\mathrm{SGD}}=\frac{\frac{\left(\mathrm{Sal}_{\mathrm{OW}}-\mathrm{Sal}_{\mathrm{SW}}\right) \times \mathrm{V}}{\mathrm{t}}}{\text { Sal }_{\text {ow }}}
$$

where, $S_{a l} l_{o w}$ and $S a l_{s w}$ represent salinity values of open water and coastal surface waters. As in Eq. $1, V$ is the volume of coastal water affected by SGD $\left(\mathrm{m}^{3}\right)$; and $t$ is the coastal water residence time (d). We used the same end-member values as in the ${ }^{224} \mathrm{Ra}$ mass balance. Note that this mass 321 balance assumes a groundwater salinity end-member $\left(\mathrm{Sal}_{S G D}\right)$ of zero in order to quantify only 322 the fresh component of SGD (Knee et al., 2010).

\subsection{3 ${ }^{222} \mathrm{Rn}$ surveys and groundwater seepage assessment} Seawater ${ }^{222} \mathrm{Rn}$ concentrations were measured in surface coastal waters (at about $0.3 \mathrm{~m}$ 325 depth) in July, December of 2015, and July of 2016 along all sections using a RAD AQUA set up (Durridge Co., Inc.) as described in Dulaiova et al. (2005) and further improved by Dimova et

327 al. (2009). To obtain radon-in-water concentrations, the measured radon-in-air was corrected 328 using the temperature-dependent Ostwald's solubility coefficient (Macintyre et al., 1995) (Eq. 3):

$$
\alpha=0.105+0.405 \mathrm{e}^{(-0.05027 \times \mathrm{T})}
$$

330 where $T\left({ }^{\circ} \mathrm{C}\right)$ is the water temperature, measured in 2 min intervals using a temperature data 331 logger $\left(\mathrm{HOBO}^{\circledR}\right.$, Onset ${ }^{\circledR}$ Inc.). Analytical uncertainties of ${ }^{222} \mathrm{Rn}$ in water were most of the time 332 lower to 10\%. The RAD AQUA system was run stationary for at least 20 min at the beginning of 
333 all surveys to achieve water/air and radioactive equilibrium (Dimova et al., 2009), and set up to 334 measure in 10 min intervals while moving at boat speed of $2 \mathrm{~km} \mathrm{~h}^{-1}$ to allow for detection of 335 rapid ${ }^{222} \mathrm{Rn}$ changes. These data were coupled with GPS coordinates to be mapped later.

336 Diffuse groundwater seepage was quantified using a ${ }^{222} \mathrm{Rn}$ mass balance (box model) as 337 described in Burnett and Dulaiova (2003) during July of 2015 and 2016, and December of 2016. 338 To evaluate diffuse groundwater seepage using a ${ }^{222} \mathrm{Rn}$ mass balance (Eq. 4), ${ }^{222} \mathrm{Rn}$ time-series (1 339 - 2 days long) were conducted in the Maro Cliff and Cantarrijan Beach seepage area. For this 340 study, this mass balance was modified to account for radon inputs to the sea from a small 341 groundwater-fed waterfall (Maro Creek) (Fig. 1). Radon fluxes $\left(F_{G W}\right)\left(\mathrm{dpm} \mathrm{m} \mathrm{m}^{-2} \mathrm{~h}^{-1}\right.$ from 342 groundwater discharge were determined using mass balance equation where total ${ }^{222} \mathrm{Rn}$ inputs to 343 the water column are balanced by radon:

$$
\mathrm{F}_{\mathrm{GW}}=\mathrm{F}_{\mathrm{Atm}}+\mathrm{F}_{\mathrm{Mix}}-\mathrm{F}_{\text {Waterfall }}-\mathrm{C}_{\mathrm{Ra}}-\mathrm{F}_{\text {Diff }}
$$

345 where $F_{A t m}$ is the ${ }^{222} \mathrm{Rn}$ atmospheric evasion fluxes through the water/air interphase; $F_{\text {Mix }}$ are 346 mixing losses due to tidal variations and horizontal mixing; $F_{\text {waterfall }}$ are fluxes of ${ }^{222} \mathrm{Rn}$ into the 347 system from a groundwater-fed waterfall present in Maro Cliff; $C_{R a}$ is the production of ${ }^{222} \mathrm{Rn}$ 348 from ${ }^{226} \mathrm{Ra}$ decay within the water column; and $F_{\text {Diff }}$ is ${ }^{222} \mathrm{Rn}$ diffusion flux from seabed 349 sediments.

350 To assess the contribution of ${ }^{222} \mathrm{Rn}$ from Maro Creek the radon flux from the creek $351\left(F_{\text {waterfall }}\right)$ was calculated by multiplying the average creek radon concentration by the water flux 352 which was based of flowmeter measurements and specific area of discharge. This correction was 353 only done during Creek flow regime. Corrections for the production of ${ }^{222} \mathrm{Rn}$ from 354 dissolved ${ }^{226} \mathrm{Ra}$ (i.e. supported radon) in coastal waters $\left(C_{R a}\right)$ were done utilizing the Mn-fiber 355 collected in September of 2006 (one sample) and in July of 2016 (two samples) in Maro Cliff 
and Cantarrijan Beach at the time series stations. The average concentration (September 2006

357 and July 2016) was applied in the ${ }^{222} \mathrm{Rn}$ mass balance. The procedure follows the technique

358 described in details in (Charette et al., 2001). The ${ }^{226}$ Ra equilibrated samples were counted via

359 gamma spectrometry (HPGe well detector, Canberra GCW3522) using the ${ }^{214} \mathrm{~Pb}$ peak at 352

$360 \mathrm{keV}$. Atmospheric evasion of ${ }^{222} \mathrm{Rn}\left(F_{\text {Atm }}\right)$ was calculated based on the water/air interphase ${ }^{222} \mathrm{Rn}$

361 concentration gradient $\left(\mathrm{dpm} \mathrm{m}{ }^{-3}\right),{ }^{222} \mathrm{Rn}$ Ostwald solubility coefficient, and ${ }^{222} \mathrm{Rn}$ gas transfer

362 velocity $\left(\mathrm{k}, \mathrm{m} \mathrm{h}^{-1}\right)$. The gas transfer velocity $\left(\mathrm{m} \mathrm{h}^{-1}\right)$ was calculated using Eq. 5 as described in

363 Macintyre et al. (1995):

364

$$
\mathrm{k}(600)=0.45 \times \mathrm{u}_{10^{1.6}}\left(\frac{\mathrm{s}_{\mathrm{c}}}{600}\right)^{-\mathrm{b}}
$$

365

366

367 377 then calculated (Eq. 7) by dividing SGD-derived ${ }^{222} \mathrm{Rn}$ fluxes by the representative 378 groundwater ${ }^{222} \mathrm{Rn}$ concentration end-member $\left(R n_{S G D}, \mathrm{dpm} \mathrm{m}^{-3}\right)$ (Burnett and Dulaiova, 2003).

Molecular diffusion flux of ${ }^{222} \mathrm{Rn}$ from seabed sediments $\left(F_{\text {Diff }}\right)$ was determined using the approach described in Martens et al. (1980).

After all corrections were made, negative fluxes were considered mixing losses $\left(F_{\text {Mix }}\right)$. The pore water ${ }^{222} \mathrm{Rn}$ concentration and porosity of sediments were determined based on the procedure reported in Corbett et al. (1998). Groundwater seepage velocity (SGD, $\mathrm{cm} \mathrm{d}^{-1}$ ) was 
The groundwater end-member $\left(R n_{S G D}\right)$ was assessed in groundwater collected from a small cavity in the travertine cliff located $1 \mathrm{~m}$ a.s.l. in Maro Cliff, and GW-Well in Cantarrijan Beach (Fig.1). Groundwater ${ }^{222} \mathrm{Rn}$ concentrations were analyzed with a RAD7 using a $\mathrm{RAD} \mathrm{H}_{2} \mathrm{O}$ set up in duplicate $250 \mathrm{~mL}$ samples.

$$
\mathrm{SGD}=\frac{\mathrm{F}_{\mathrm{GW}}}{\mathrm{Rn}_{\mathrm{SGD}}}
$$

In order to calculate groundwater fluxes $\left(F_{S G D}, \mathrm{~m}^{3} \mathrm{~d}^{-1}\right)$, the obtained seepage velocities were multiplied by the total area through which SGD occurs using Eq. 8:

$$
\mathrm{F}_{\mathrm{SGD}}=\mathrm{SGD} \times \mathrm{A}
$$

where $S G D$ represents seepage velocity $\left(\mathrm{cm} \mathrm{d}^{-1}\right)$, and $A$ is the seepage area $\left(\mathrm{m}^{2}\right)$. To constrain the seepage area $(A)$ at the beach face, we conducted a high-resolution ${ }^{222} \mathrm{Rn}$ survey by manually moving a small boat at a speed of $15 \mathrm{~m} \mathrm{~h}^{-1}$. For more precise results, during this survey, the RAD AQUA system was let to equilibrate for 20 min every 2 - $10 \mathrm{~m}$ of shoreline. The highresolution ${ }^{222} \mathrm{Rn}$ survey data was mapped using a linear ordinary kriging interpolation method (ArcGIS 10), each concentration interval was then contoured (using the ArcGIS 10 contour spatial analyst) to obtain ${ }^{222} \mathrm{Rn}$ concentration isolines. The seepage area $(A)$ was delineated by creating a polygon that followed the $35 \times 10^{3} \mathrm{dpm} \mathrm{m}^{-3}$ isoline as a threshold in Maro Cliff and 6 $\times 10^{3} \mathrm{dpm} \mathrm{m}^{-3}$ in Cantarrijan Beach. The seepage area $\left(\mathrm{m}^{2}\right)$ was obtained by calculating the polygon geometry based on the ETRS 1989 UTM Zone 30N projected coordinate system.

\subsubsection{Fresh SGD assessment in diffuse seepage}

As defined by Taniguchi et al. (2002), diffuse groundwater seepage is comprised of two components: (1) a fresh (meteoric) groundwater component and (2) a recirculated seawater component. To calculate the fresh water component in seepage areas of the study site (e.g. in Cantarrijan Beach), we applied a salinity mixing model (Eqs. 9 and 10) as described in 
402 Taniguchi et al., (2005) and used by many others (e.g. Charette et al., 2007; Taniguchi et al., 403 2008; Santos et al., 2009). The approach relies on two basic equations:

$$
\begin{gathered}
\mathrm{f}_{\mathrm{FSGD}}+\mathrm{f}_{\mathrm{RSGD}}=1 \\
\mathrm{Sal}_{\mathrm{FSGD}} \times \mathrm{f}_{\mathrm{FSGD}}+\mathrm{Sal}_{\mathrm{RSGD}} \times \mathrm{f}_{\mathrm{RSGD}}=\mathrm{Sal}_{\mathrm{SGD}} \times \mathrm{f}_{\mathrm{SGD}}
\end{gathered}
$$

406

407

408

409

410

where $f_{F S G D}$ and $f_{R S G D}$ represent the fresh and recirculated fractions of SGD, and $S a l_{F S G D}$ and $S_{R S G D}$ are the salinity values measured in fresh groundwater (GW-Well) and maximum recirculated salinity (GW-Pz-4).

\subsection{Direct groundwater flow measurements}

\subsubsection{Flowmeter measurements of coastal springs and creeks}

The location of coastal springs and inland springs feeding groundwater-fed creeks were identified via field observations. The discharge from the identified coastal springs (Doncellas, Barranco Maro, Huerto Romero, Maro Beach, and Alberquillas) and groundwater-fed creeks (Caleta Creek, Tierras Nuevas Creek, and Miel Creek) entering the sea, were measured using a flowmeter (OTT C2, OTT Hydromet $\mathrm{GmbH}$ ) with an accuracy of $\pm 10 \%$. Channel widths were between $10 \mathrm{~cm}$ and $140 \mathrm{~cm}$ and depths were below $30 \mathrm{~cm}$ in all springs and creeks. Flow velocity measurements at the average water depths were recorded in $10 \mathrm{~cm}$ intervals across the stream cross section right before discharge into the sea. Water fluxes were calculated for each interval multiplying width $(10 \mathrm{~cm})$ and depth by flow velocity. Total water flux $\left(\mathrm{m}^{3} \mathrm{~d}^{-1}\right)$ was then calculated by adding water fluxes in all intervals. To observe differences between dry and wet periods measurements were conducted during July and December of 2016.

\subsubsection{Seepage meter measurements of diffuse seepage}

To verify ${ }^{222} \mathrm{Rn}$-based SGD estimates, we deployed multiple seepage meters in July of 2016. Lee-type seepage meters, built following the procedure described in Lee (1977) were 
425 deployed near the ${ }^{222} \mathrm{Rn}$ time series station in areas of active groundwater seepage (Maro Cliff 426 and Cantarrijan Beach) during July of 2016. Four seepage meters were deployed in Maro Cliff 427 and nine in Cantarrijan Beach to obtain a representative evaluation of the seepage area. These 428 were made of a bottomless $60 \mathrm{~L}$ plastic drum with an area of $0.12 \mathrm{~m}^{2}$ with a plastic bag attached 429 to a two-way valve (Isiorho and Meyer, 1999; Schincariol and McNeil, 2002; Rosenberry, 2008).

430 The seepage meters were submerged and slowly inserted in the sediments leaving $2 \mathrm{~cm}$ of space 431 between the sediments and the drum interior top. The seepage meter was positioned inclined in 432 order to leave the valve side slightly higher allowing any gas to escape before plastic bag 433 attachment; the water volume entering the plastic bag and time elapsed were then recorded (Lee, 434 1977). Seepage velocities (SGD, $\mathrm{cm} \mathrm{d}^{-1}$ ) were calculated using Eq. 11 modified from Lee (1977):

$$
\mathrm{SGD}=\frac{68.79 \times \mathrm{V}}{\mathrm{t}}
$$

where $V$ is volume of water entering the plastic bag $(\mathrm{mL})$; $t$ is the time elapsed (s), and 68.79 is a

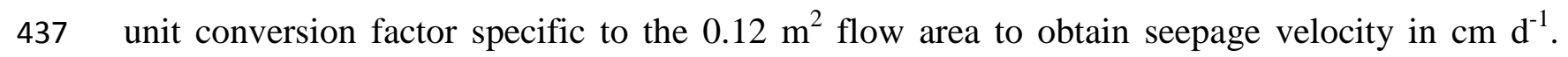
438 Groundwater discharge $\left(\mathrm{m}^{3} \mathrm{~d}^{-1}\right)$ was calculated using Eq. 8.

\subsection{Groundwater chemistry, stable isotopic composition, and $\mathrm{NO}_{3}{ }^{-}$fluxes}

During July and December of 2015, and in July of 2016 water stable isotopes $\left(\delta^{2} \mathrm{H}\right.$ and

$\left.441 \delta^{18} \mathrm{O}\right), \mathrm{NO}_{3}{ }^{-}$and $\mathrm{SO}_{4}{ }^{2-}$ were measured in all points of groundwater discharge to the sea, Maro 442 Spring, and a well located in the conglomerate section (Nerja Cave) (Fig. 1). A total of 23 443 samples were collected in Maro Cliff and Cantarrijan Beach (GW-Well) $(\mathrm{n}=4)$, all subaerial 444 coastal springs (Doncellas, Barranco Maro, Huerto Romero, Maro Beach, and Alberquillas, n = 445 14), and groundwater-fed creeks (Maro Creek and Miel Creek, $n=5$ ) during all sampling 446 campaigns. 

measurement, diluted to $1 \mathrm{mS} \mathrm{cm}{ }^{-1}$, and filtered before analysis. $\mathrm{NO}_{3}{ }^{-}$and $\mathrm{SO}_{4}{ }^{2-}$ concentrations were analyzed at the CEHIUMA (Center of Hydrogeology of the University of Malaga) 450 laboratory via ionic chromatography (Metrohm 881 Compact IC Pro) with an accuracy of $\pm 2 \%$. 451 Water stable isotopes $\left(\delta^{2} \mathrm{H}\right.$ and $\left.\delta^{18} \mathrm{O}\right)$ were also analyzed at the CEHIUMA using a Laser Cavity 452 Ring-Down Spectrometer (Picarro CRDS L2120-i) with accuracies of $\pm 1 \%$ and $\pm 0.1 \%$ for $\delta^{2} \mathrm{H}$ 453 and $\delta^{18} \mathrm{O}$ respectively. Isotopic ratios were calculated using the Vienna Standard Mean Ocean 454 Water (VSMOW, in \%o). Nitrate fluxes $\left(F_{\mathrm{NO}_{3}}, \mathrm{mmol}^{-1}\right)$ to the sea were calculated by 455 multiplying $\mathrm{NO}_{3}{ }^{-}$concentrations at each point of discharge during each sampling campaign by 456 corresponding measured groundwater flux (Eq. 12):

$$
\mathrm{F}_{\mathrm{NO}_{3}^{-}}=\mathrm{F}_{\mathrm{SGD}} \times\left[\mathrm{NO}_{3}^{-}\right]
$$

458 where $\left[\mathrm{NO}_{3}{ }^{-}\right]$represents nitrate concentrations $\left(\mathrm{mmol} \mathrm{m}{ }^{-3}\right)$, and $F_{S G D}$ is the groundwater flux $459 \quad\left(\mathrm{~m}^{3} \mathrm{~d}^{-1}\right)$

\section{Results}

\subsection{Detecting submarine spring discharge using ${ }^{224} \mathrm{Ra}$ and salinity}

\subsection{1 ${ }^{224}$ Ra activities in seawater and groundwater} concentrations in surface waters along the study area was $17 \pm 2 \mathrm{dpm} \mathrm{m}^{-3}(\mathrm{n}=30)$ ranging from $46656 \pm 4 \mathrm{dpm} \mathrm{m}^{-3}$ to $8 \pm 1 \mathrm{dpm} \mathrm{m}^{-3}$ (Fig. 3; Supplementary material Table A.1). In general, ${ }^{224} \mathrm{Ra}$ 467 values along the schist and karst sections of the study area were lower compared to other 468 Mediterranean regions (e.g. Moore, 2006; García-Solsona et al., 2010; Rodellas et al., 2014). 469 However, two distinctive ${ }^{224}$ Ra-high anomalies in coastal surface waters were identified during 
470 this survey; these were associated with water inputs with average salinity of 0.8 from the 471 groundwater-fed Miel Creek (56 $\pm 4 \mathrm{dpm} \mathrm{m}^{-3}$ ), and the three clustered submarine springs

472 discharging from Cantarrijan Caves $\left(51 \pm 4 \mathrm{dpm} \mathrm{m}^{-3}\right)$ located in the Cantarrijan area (Fig. 3).

473 Miel Creek (average salinity anomaly $=0.3$ ), which flows through the marble formation of 474 Alberquillas Aquifer Unit for a total length of approximately $5 \mathrm{~km}$, has a perennial flow, a firm 475 indication that it is fed by groundwater (Fig. 3). Indeed, a set of springs located predominantly in 476 the southernmost section of the Creek at the marble-schist contact have been observed to 477 maintain the constant creek flow regime all year long. The second peak of ${ }^{224}$ Ra was located 478 right above the three submarine springs (Cantarrijan Caves) near Cantarrijan Beach. 479 Average ${ }^{224}$ Ra values significantly higher $\left(20 \pm 7 \mathrm{dpm} \mathrm{m}^{-3}\right)$ than offshore background activity (8 $480 \pm 1 \mathrm{dpm} \mathrm{m}^{-3}$ ) were detected also along the karst section from Cantarrijan to Cerro Gordo, where 481 Alberquillas Aquifer Unit is directly in contact with the sea (Fig. 3).

482

483

Figure 3: Interpolated ${ }^{224}$ Ra activity concentrations in September of 2010 along the schist and karst 484 sections. Two areas of high ${ }^{224} \mathrm{Ra}$ in coastal waters were identified in the schist section near 485 groundwater-fed Miel Creek $\left(56 \pm 4 \mathrm{dpm} \mathrm{m}^{-3}\right)$, and the three clustered submarine springs 486 discharging from Cantarrijan Caves $\left(51 \pm 4 \mathrm{dpm}^{-3}\right)$ located in the Cantarrijan area (karst 487 section).

488

Radium-224 in groundwater in Cantarrijan Beach varied from $660 \pm 30 \mathrm{dpm} \mathrm{m}^{-3}$ (salinity anomaly $=1.6)$ in a shallow well $(G W-W e l l$, Supplementary material Table A.1) to $5500 \pm 430$

$491 \mathrm{dpm} \mathrm{m}^{-3}$ (salinity = 31.1) in five piezometers installed on the shore (GW-Pz-1-5, Supplementary 492 material Table A.1). Activity of ${ }^{224} \mathrm{Ra}$ in groundwater collected from two wells in the karstic 493 marble (GW-CG-1 and GW-CG-2, Supplementary material Table A.1) showed similar activities, 
$4941260 \pm 90 \mathrm{dpm} \mathrm{m}^{-3}$ and $1020 \pm 80 \mathrm{dpm} \mathrm{m}^{-3}$ with salinities of 2.2 and 0.6 respectively. The 495 variation of ${ }^{224} \mathrm{Ra}$ concentrations in GW-Well and Pz-1-5 (Fig 5c) can be explained by the 496 seawater recirculation in the beach sediments. Radium concentration in fresh waters is very low 497 due to adsorption onto particles. However, in pore water with higher ionic strength (i.e. brackish 498 and salt water) radium desorbs due to cation exchange. This process increases dissolved ${ }^{224} \mathrm{Ra}$ 499 concentration (Webster et al., 1995).

\subsubsection{Salinity anomalies}

The average salinity in coastal waters of the study site during continuous measurements 502 in September of 2010 was $36.4 \pm$ 0.2, during May of 2015 was $36.6 \pm 4.0$, in July 2015 was 37.2 $503 \pm 1.2$, and in December of 2015 was $34.5 \pm 1.7$. A negative salinity anomaly of -1.2 to -1.7 was 504 observed during all sampling campaigns in the conglomerate section in the vicinity of multiple 505 coastal springs (Doncellas, Barranco Maro, Huerto Romero, and Maro Beach) and two 506 groundwater-fed creeks (Caleta Creek, and Tierras Nuevas Creek) (Fig. 4). However, in the 507 schist section where Alberquillas coastal spring enters the sea, salinity was generally similar to 508 the average throughout the coastline with a value of 36.3 in September of 2010, 37.1 in May of 509 2015, 37.1 in July of 2015, and 34.4 in December of 2015. Similarly, small salinity variation

510 (Fig. 4) associated with high ${ }^{224}$ Ra (Fig. 3) was observed near the outlet of the groundwater-fed 511 Miel Creek.

512

513 Figure 4: Salinity anomaly map showing combined results from May, July, and December of 2015.

514 Two areas of negative salinity anomalies were found in the conglomerate (salinity anomaly $=\mathbf{- 1 . 2}$ to $515-1.7$ ) and karst (salinity anomaly $=-0.3$ to -1.0 ) sections almost perfectly aligned with their 516 delineated extent. 
In the karst section (Fig. 1), where the karstic marble formation is in contact with the sea,

519 negative salinity anomalies (-0.3 to -1.0) coincided with previously observed high ${ }^{224} \mathrm{Ra}$

520 concentrations in coastal waters near the Palomas and Sifon Caves submarine springs. The

521 largest salinity anomaly (-1.0) in the karst section was found in Cantarrijan Beach, which could

522 be related to Cantarrijan Caves springs. However, the lowest values are distributed along the

523 beach area, slightly deviated to the East off Cantarrijan Caves, where groundwater seepage

524 through marine sediments can, therefore, also be occurring.

525

526

527

528

529

530

531

532

533

534

535

536

537

538

539

540

\subsection{Evaluating submarine spring discharge using ${ }^{224} \mathrm{Ra}$ and salinity}

\subsection{1 ${ }^{224} \mathrm{Ra}$ mass balance}

To assess groundwater discharge in the areas of high ${ }^{224} \mathrm{Ra}\left(12-51 \mathrm{dpm} \mathrm{m}{ }^{-3}\right)$ and negative salinity anomalies (-0.3 to -1.0 ), i.e. the areas of Cantarrijan Caves, Palomas Cave, and Sifon Cave submarine springs (Figs. 2 and 3), we used a ${ }^{224}$ Ra mass balance following Moore (1996) and Charette et al. (2001; Eq.1). The main assumption in this approach is that the ${ }^{224} \mathrm{Ra}$ excess in the karst section is considered to be originated solely by submarine springs.

SGD through Cantarrijan Caves was quantified using the ${ }^{224}$ Ra coastal water end-member measured in SW-6, SW-7, SW-13 and SW-24 $\left(R a_{s w}=25 \pm 2 \mathrm{dpm} \mathrm{m}^{-3}, \mathrm{n}=4\right)$, where SW-7 was collected at the depth of discharge $(8 \mathrm{~m})$. Average offshore background activity $\left(8 \pm 1 \mathrm{dpm} \mathrm{m}^{-3}\right)$ measured in SW-23, SW-27, SW-29, and SW-30 was used as the open water end-member $\left(R a_{o w}\right)$ (Supplementary material Table A.1). Groundwater samples collected from well GW-CG-1 (Fig.1), which is the closest well to the submarine springs and is representative of the marble aquifer formation, was used as the groundwater end-member $\left(1260 \pm 90 \mathrm{dpm} \mathrm{m}^{-3}\right.$, salinity $\left.=2.2\right)$. Following the same approach, SGD was also evaluated in the area of Palomas Cave using SWSW-20, SW-21, and SW-25 $\left(R a_{s w}=18 \pm 2 \mathrm{dpm} \mathrm{m} \mathrm{m}^{-3}, \mathrm{n}=3\right)$, where SW-21 was collected at $15 \mathrm{~m}$ 
541 depth of discharge. In Sifon Cave samples SW-14, SW-22, and SW-26 were used as the coastal 542 water end-member. The same open water $\left(R a_{o w}\right)$ and groundwater $\left(R a_{S G D}\right)$ end-members were 543 used: $1260 \pm 90 \mathrm{dpm} \mathrm{m}^{-3}$ and $8 \pm 1 \mathrm{dpm} \mathrm{m}^{-3}$ respectively (Fig. 3; Table 1).

The estimated groundwater fluxes $\left(F_{S G D}\right)$ through Cantarrijan Caves was $4.7 \pm 0.5 \times$ $54510^{3} \mathrm{~m}^{3} \mathrm{~d}^{-1}$, at Palomas cave was $4.3 \pm 0.5 \times 10^{3} \mathrm{~m}^{3} \mathrm{~d}^{-1}$, and for Sifon Cave was $3.7 \pm 0.4 \times 10^{3} \mathrm{~m}^{3}$ $546 \mathrm{~d}^{-1}$. This represents a total flux of $12.8 \pm 1.4 \times 10^{3} \mathrm{~m}^{3} \mathrm{~d}^{-1}$ via submarine springs, where reported 547 errors are based on analytical uncertainties of ${ }^{224}$ Ra measurements.

\subsubsection{Salinity mass balance}

The salinity anomaly created by the Cantarrijan, Palomas, and Sifon Caves in the karst section (Fig. 4, Table 1) allowed us to construct individual mas-balances at each location and

551 calculate SGD independently of the ${ }^{224} \mathrm{Ra}$ approach. Considering that the salinity of groundwater 552 discharge of these springs is the same value of the endmember used for the ${ }^{224}$ Ra method (Table 553 1), and applying Eq. 2 we calculated a total groundwater flux of $0.8 \pm 0.1 \times 10^{3} \mathrm{~m}^{3} \mathrm{~d}^{-1}$ in 554 Cantarrijan Caves, $0.9 \pm 0.1 \times 10^{3} \mathrm{~m}^{3} \mathrm{~d}^{-1}$ in Palomas Cave, and $0.5 \pm 0.1 \times 10^{3} \mathrm{~m}^{3} \mathrm{~d}^{-1}$ through 555 Sifon Cave; representing a total of $2.3 \pm 0.2 \times 10^{3} \mathrm{~m}^{3} \mathrm{~d}^{-1}$.

\subsection{Assessing diffuse groundwater seepage using a ${ }^{222} \mathrm{Rn}$ mass balance and seepage}

\section{meter measurements}

\subsection{1 ${ }^{222} \mathrm{Rn}$ distribution in seawater}

High ${ }^{222} \mathrm{Rn}$ concentrations were measured in two distinct areas in the Maro Cliff area

560 (conglomerate section) and Cantarrijan Beach (karst section) with maximum concentrations of $56144 \pm 3 \times 10^{3} \mathrm{dpm} \mathrm{m}^{-3}$ and $30 \pm 2 \times 10^{3} \mathrm{dpm} \mathrm{m}^{-3}$ respectively (Fig. 5). In general, along the 562 conglomerate section, ${ }^{222} \mathrm{Rn}$ activities were within background levels $\left(1.9 \pm 0.6 \times 10^{3} \mathrm{dpm} \mathrm{\textrm {m } ^ { - 3 }}\right)$ 563 with the mentioned exception of a cove in the Maro Cliff area where the travertine formation is 
564 in contact with the sea. In this location, a 15-m travertine cliff ends in coarse seabed sand 565 through which groundwater seepage was identified underlying a 1.5-m water column. In the 566 karst section, high ${ }^{222} \mathrm{Rn}$ was detected only along the Cantarrijan Beach where a steep ravine,

567 formed in the marble formation, ends in a big opening comprised of coarse sand, pebbles, 568 cobbles, and even boulders suggesting flash flooding events in the ravine after significant 569 precipitations.

570

571 Figure 5: Radon-222 distribution map based on surveys during July and December of 2015, and 572 July of 2016. Two radon peaks were in found in Maro Cliff (conglomerate section) and Cantarrijan 573 Beach (karst section) with maximum concentrations of $44 \pm 3 \times 10^{3} \mathrm{dpm} \mathrm{m}^{-3}$ and $30 \pm 2 \times 10^{3} \mathrm{dpm}$ $574 \mathbf{m}^{-3}$ respectively.

575

576

577

578

579

580

581

582

583

584

585

586

587

\subsubsection{Groundwater discharge assessments in the conglomerate section (Maro}

\section{Cliff)}

Diffuse groundwater seepage was identified in this area during all ${ }^{222} \mathrm{Rn}$ surveys (July and December of 2015, and July of 2016) suggesting the seepage is maintained by base groundwater flow (Fig. 6a). We calculated that ${ }^{222} \mathrm{Rn}$ contribution from the waterfall (i.e., $\mathrm{F}_{\text {Waterfall }}$ ) was on average $16 \pm 6 \mathrm{dpm} \mathrm{m}^{-2} \mathrm{~d}^{-1}$ (Table 2). To account for the production of ${ }^{222} \mathrm{Rn}$ from ${ }^{226} \mathrm{Ra}$ dissolved in coastal waters $\left(\mathrm{C}_{\mathrm{Ra}}\right)$, we used the averaged concentration $(280 \pm 50 \mathrm{dpm}$ $\left.\mathrm{m}^{-3}, \mathrm{n}=3\right)$ measured in September of $2006\left(306 \pm 40 \mathrm{dpm} \mathrm{m}^{-3}, \mathrm{n}=1\right)$ and July of $2016(260 \pm 50$ dpm $\mathrm{m}^{-3}, \mathrm{n}=2$ ) at the time series station (Table 2, Fig. 6b). Atmospheric evasion $\left(F_{\text {Atm }}\right)$ was calculated using Eq 8 except in July of 2015, when wind speed was much higher $\left(8 \mathrm{~m} \mathrm{~s}^{-1}\right)$ and we used Eq. 6 instead. Diffusive flux of ${ }^{222} \mathrm{Rn}$ from seabed sediments $\left(F_{\text {Diff }}\right)$ was $619 \pm 57 \mathrm{dpm} \mathrm{m}{ }^{-2}$ $\mathrm{d}^{-1}$ accounting for only $0.2-0.5 \%$ of total ${ }^{222} \mathrm{Rn}$ fluxes (Fig. 7). As one would expect in coastal 

604 study.

waters with little protection against wind and waves, mixing losses in this study represent the main ${ }^{222} \mathrm{Rn}$ loss in the model (Fig. 7).

Figure 6: (a) Groundwater seepage velocity averaging results from radon mass balance and seepage meters in areas of diffuse seepage (Maro Cliff and Cantarrijan Beach). Radon distribution in (b) Maro Cliff (conglomerate section) and (c) Cantarrijan Beach (karst section) where cylinder symbols represent seepage meter locations and the star radon time series stations.

The ${ }^{222} \mathrm{Rn}$ concentrations in groundwater end-members $\left(R n_{S G D}\right)$ were $350 \pm 50 \times 10^{3} \mathrm{dpm}$ $\mathrm{m}^{-3}, 440 \pm 60 \times 10^{3} \mathrm{dpm} \mathrm{m}^{-3}$, and $320 \pm 30 \times 10^{3} \mathrm{dpm} \mathrm{m}^{-3}$ during July, December of 2015, and July of 2016 respectively, with an average value of $370 \pm 50 \times 10^{3} \mathrm{dpm} \mathrm{m}^{-3}$. Based on these estimates (Table 2) and applying Eq. 4, we obtained average seepage velocities of $39 \pm 10 \mathrm{~cm} \mathrm{~d}^{-1}$ $(\mathrm{n}=43)$ in July 2015, $40 \pm 11 \mathrm{~cm} \mathrm{~d}^{-1}(\mathrm{n}=78)$ in December of 2015, and $38 \pm 10 \mathrm{~cm} \mathrm{~d}^{-1}(\mathrm{n}=90)$ during July of 2016. Reported SGD uncertainties are calculated based on ${ }^{222} \mathrm{Rn}$ variations from all samples collected in the area to obtain the groundwater end-members $\left(R n_{S G D}\right)$ (Burnett et al., 2007); which ranged from $320 \pm 30 \times 10^{3} \mathrm{dpm} \mathrm{m}^{-3}$ to $690 \pm 50 \times 10^{3} \mathrm{dpm} \mathrm{m}^{-3}(\mathrm{n}=8)$ during this

Utilizing Eq. 8 we estimated total groundwater fluxes based on the ${ }^{222} \mathrm{Rn}$ box model to be $3.0 \pm 0.8 \times 10^{3} \mathrm{~m}^{3} \mathrm{~d}^{-1}$ during July of 2015, $3.1 \pm 0.8 \times 10^{3} \mathrm{~m}^{3} \mathrm{~d}^{-1}$ in December of 2015, and $2.9 \pm$ $0.7 \times 10^{3} \mathrm{~m}^{3} \mathrm{~d}^{-1}$ in July of 2016 (Table 2). Using Eq. 11 an average seepage velocity of $28 \pm 6 \mathrm{~cm}$ $\mathrm{d}^{-1}$ (Table 3) was calculated. This assessment is in good agreement with the average ${ }^{222} \mathrm{Rn}$-based value of $38 \pm 10 \mathrm{~cm} \mathrm{~d}^{-1}$. Using Eq. 8 and a seepage area of $7.7 \times 10^{3} \mathrm{~m}^{2}$ based on the radon concentration (Fig. 6b), we calculated a groundwater flux of $2.1 \pm 0.4 \times 10^{3} \mathrm{~m}^{3} \mathrm{~d}^{-1}$ in July of 2016 (Table 3). 


\subsubsection{Groundwater fluxes in the karst section (Cantarrijan Beach)}

614 indicated a strong seasonality in seawater ${ }^{222} \mathrm{Rn}$ concentrations, with an average of $75 \pm 3 \times$

$61510^{3} \mathrm{dpm} \mathrm{m}^{-3}$ in December and $11 \pm 2 \times 10^{3} \mathrm{dpm}^{-3}$ in July, suggesting higher SGD during the 616 wet period. The average ${ }^{226} \mathrm{Ra}$ concentration $\left(\mathrm{C}_{\mathrm{Ra}}\right)$ was $170 \pm 40 \mathrm{dpm} \mathrm{m}{ }^{-3}$ measured in September 617 of $2006\left(169 \pm 30 \mathrm{dpm} \mathrm{m}^{-3}, \mathrm{n}=1\right)$ and July of $2016\left(170 \pm 40 \mathrm{dpm} \mathrm{m}^{-3}, \mathrm{n}=2\right)$ (Table 2). The 618 variation of the groundwater ${ }^{222} \mathrm{Rn}$ end-member $\left(240 \pm 60 \times 10^{3} \mathrm{dpm} \mathrm{m}^{-3}\right.$ to $350 \pm 40 \times 10^{3} \mathrm{dpm}$ $619 \mathrm{~m}^{-3}, \mathrm{n}=6$ ) was used to calculate the final groundwater discharge flux uncertainties. Seepage 620 velocities in December and July were on average $52 \pm 8 \mathrm{~cm} \mathrm{~d}^{-1}(\mathrm{n}=61)$ and $22 \pm 3 \mathrm{~cm} \mathrm{~d}^{-1}(\mathrm{n}=$ 621 115) respectively (Table 3).

We found that groundwater seepage occurs only in the westernmost sector at the end of 623 the Cantarrijan Ravine (Fig. 6c). Seepage velocities, determined from all seepage meters 624 deployed along the beach, show that groundwater seepage ceases exactly at the location where 625 seepage meter SM-4 was deployed (Fig. 6c). We used this as a criterion to define the seepage

626 face and decided to use the ${ }^{222} \mathrm{Rn}$ contour line of $6 \pm 1 \times 10^{3} \mathrm{dpm} \mathrm{m}^{-3}$ to calculate the seepage 627 area, and averaged SM-1-4 to determine a seepage velocity of $23 \pm 7 \mathrm{~cm} \mathrm{~d}^{-1}$. Using the ${ }^{222} \mathrm{Rn}$ 628 method we found that the total diffuse groundwater seepage in the Cantarrijan Beach area ranged 629 from $2.3 \pm 0.3 \times 10^{3} \mathrm{~m}^{3} \mathrm{~d}^{-1}$ during the wet period to $0.9 \pm 0.1 \times 10^{3} \mathrm{~m}^{3} \mathrm{~d}^{-1}$ during dry conditions; 630 whereas seepage meter measurements resulted in $0.9 \pm 0.2 \times 10^{3} \mathrm{~m}^{3} \mathrm{~d}^{-1}$.

Figure 7: Radon fluxes result of each component of the mass balance box model during all sampling campaigns in Maro Cliff (conglomerate section) and Cantarrijan Beach (karst section). The largest tracer losses occurred via mixing due to the high exposure of both areas to waves and currents. 
635

636

637

638

639

640

641

642

643

644

645

646

647

648

649

650

651

652

653

654

655

656

657

658

Greater difference in SGD- ${ }^{222} \mathrm{Rn}$ fluxes was found between wet periods (December) and dry periods (July) in Cantarrijan Beach compared to Maro Cliff.

During all sampling campaigns, the groundwater sampled from the shallow well at Cantarrijan Beach (GW-Well, Fig.1) always had salinity values of 1.6 - 3.2. During September of 2010, salinities of 6.6 - 31.1 were also observed in pore water samples collected in all five piezometers installed on the beach (GW-PZ-1-5, Fig 1). Based on the salinity mixing model (using Eqs. 9 and 10) we calculated that the fresh fraction of SGD at this site was $48 \%$ of the total groundwater seepage. Therefore, when constructing the Sierra Almijara-Alberquillas Aquifer freshwater water budget for July of 2016, only $0.4 \pm 0.1 \times 10^{3} \mathrm{~m}^{3} \mathrm{~d}^{-1}$ (representative of the $48 \%$ freshwater component) should be taken into account.

\subsection{Groundwater contribution from coastal springs and groundwater-fed creeks}

Groundwater discharge to the sea during dry conditions calculated using flowmeter measurements in July of 2016 from coastal spring Huerto Romero was $37 \pm 3 \mathrm{~m}^{3} \mathrm{~d}^{-1}$, from Maro Beach was $26 \pm 2 \mathrm{~m}^{3} \mathrm{~d}^{-1}$, from Barranco Maro was $17 \pm 1 \mathrm{~m}^{3} \mathrm{~d}^{-1}$, from Doncellas was $460 \pm 40$ $\mathrm{m}^{3} \mathrm{~d}^{-1}$, and from Alberquillas was $1060 \pm 90 \mathrm{~m}^{3} \mathrm{~d}^{-1}$ (Supplementary material Table A.2). The discharge from groundwater-fed creek Miel Creek was $1230 \pm 110 \mathrm{~m}^{3} \mathrm{~d}^{-1}$, from Caleta Creek 160 $\pm 10 \mathrm{~m}^{3} \mathrm{~d}^{-1}$, and from Tierras Nuevas Creek was $110 \pm 10 \mathrm{~m}^{3} \mathrm{~d}^{-1}$. The total discharge from all creeks was $3100 \pm 280 \mathrm{~m}^{3} \mathrm{~d}^{-1}$; which represents $33 \%$ of the total groundwater discharge in the study area.

In December of 2016, during high flow conditions, discharge from coastal springs Huerto Romero was $100 \pm 9 \mathrm{~m}^{3} \mathrm{~d}^{-1}$, from Maro Beach was $43 \pm 4 \mathrm{~m}^{3} \mathrm{~d}^{-1}$, from Barranco Maro was $69 \pm 6$ $\mathrm{m}^{3} \mathrm{~d}^{-1}$, from Doncellas was $530 \pm 50 \mathrm{~m}^{3} \mathrm{~d}^{-1}$, and from Alberquillas was $1590 \pm 140 \mathrm{~m}^{3} \mathrm{~d}^{-1}$.

Discharge via groundwater-fed Miel Creek was $1820 \pm 160 \mathrm{~m}^{3} \mathrm{~d}^{-1}$, from Caleta Creek was $220 \pm$ 
659

660

661

662

663

664

665

666

667

668

669

670

671

672

673

674

675

676

677

678

679

680

681

682

$20 \mathrm{~m}^{3} \mathrm{~d}^{-1}$, and from Tierras Nuevas Creek was $190 \pm 20 \mathrm{~m}^{3} \mathrm{~d}^{-1}$; which constitutes $4580 \pm 60 \mathrm{~m}^{3}$ $\mathrm{d}^{-1}$ or $37 \%$ of the total discharge in the study area (Supplementary material Table A.2).

4.5 Groundwater isotopic composition, water chemistry, and nitrate fluxesIsotopic values are widely scattered along a linear trend (Local Groundwater Line, LGL) with a slope of 6.06, with averages of $-42 \%$ and $-7.1 \%$ for $\delta^{2} \mathrm{H}$ and $\delta^{18} \mathrm{O}$ respectively (Figs. 8a and 8b). All samples fall between the Global Meteoric Water Line (GMWL; Craig, 1961) and the Western Mediterranean Meteoric Water Line (WMMWL; Gat and Garmi, 1970), samples collected in or derived from Maro Spring are situated slightly above the WMMWL. Deuterium values ranged from $-33 \pm 1 \%$ to $-46 \pm 1 \%$, while $\delta^{18} \mathrm{O}$ were between $-5.6 \pm 0.1 \%$ and $-7.8 \pm 0.1 \%$ o (Supplementary material Table A.2). We observed that groundwater collected from Maro Spring (conglomerate section) has the lightest isotopic signature of. $-46 \%$ and $-7.7 \%$ for $\delta^{2} \mathrm{H}$ and $\delta^{18} \mathrm{O}$ respectively. Samples collected in the conglomerate section from coastal springs Barranco Maro, Huerto Romero, Maro Beach, and groundwater-fed Maro Creek showed values that ranged from -45 and -7.6 to $-43 \%$ and $-7.2 \%$. At the point of seepage discharge in the sea, Maro Cliff showed slightly higher values of $-44 \%$ and $-7.4 \%$ for $\delta^{2} \mathrm{H}$ and $\delta^{18} \mathrm{O}$. Coastal springs Doncellas, Alberquillas, and groundwater-fed Miel Creek all located in the schist section, are grouped together with Nerja Cave (conglomerate section), showing average values of $-33 \%$ and $-5.5 \%$ for $\delta^{2} \mathrm{H}$ and $\delta^{18} \mathrm{O}$. Samples collected from GW-Well (Cantarrijan Beach), have the highest values in the study area with averages of $-22 \%$ and $-3.8 \%$ for $\delta^{2} \mathrm{H}$ and $\delta^{18} \mathrm{O}$.

Figure 8: (a) Isotopic composition $\left(\delta^{18} \mathrm{O}, \delta^{2} \mathrm{H}\right)$ of water samples collected during all sampling campaigns. Local Groundwater Line (LGL) represents the linear trend based on all groundwater samples collected in the study area. Global Meteoric Water Line (GMWL) is based on Craig, (1961) 

704 Table A.2). squares.

and the Western Mediterranean Meteoric Water Line (WMMWL) on Gat and Garmi, (1970). White color represents points of discharge in conglomerate and breccia lithology, while light grey are in travertine (conglomerate section); dark grey shows points in schist (schist section); and black color show locations in karstic marble (karst section). Maro Spring and Nerja Cave well (not points of discharge to the sea) are represented with a black and white star respectively. Water samples collected at each section (conglomerate section, schist section, ans karst section) are grouped in dashed squares. (b) Isotopic composition of samples collected from points of discharge from the travertine formation in the conglomerate section. The two groundwater end-members (Maro Spring and irrigation waters) are circled, while diffuse seepage in Maro Cliff is represented with

Groundwater sulphate $\left(\mathrm{SO}_{4}{ }^{2-}\right)$ concentrations ranged from $500 \pm 10 \mathrm{mmol} \mathrm{m}^{-3}$ in Alberquillas coastal spring to $3220 \pm 64 \mathrm{mmol} \mathrm{m}^{-3}$ in Cantarrijan Beach $(\mathrm{n}=23)$ (Supplementary material Table A.2). Samples collected in the conglomerate section from coastal springs Doncellas, Barranco Maro, Huerto Romero, Maro Beach; groundwater-fed Maro Creek, and diffuse seepage in Maro Cliff had similar $\mathrm{SO}_{4}{ }^{2-}$ concentrations ranging between 1500 and $3000 \mathrm{mmol} \mathrm{m} \mathrm{m}^{-3}$. All samples (including Maro Spring) collected from Sierra AlmijaraAlberquillas Aquifer in this area fall within $\mathrm{a} \mathrm{SO}_{4}{ }^{2-}$ concentration range of $1700-2600 \mathrm{mmol} \mathrm{m}^{-}$ ${ }^{3}$. Miel Creek and coastal spring Alberquillas (schist section) showed lower values ranging from $500 \pm 10$ to $710 \pm 14 \mathrm{mmol} \mathrm{m}^{-3}$. Water collected in Cantarrijan Beach had the highest concentration in the study area, with an average of $3030 \pm 60 \mathrm{mmol} \mathrm{m}^{-3}$ (Supplementary material

Nitrate $\left(\mathrm{NO}_{3}{ }^{-}\right)$concentrations were highest in coastal springs of the conglomerate section including Doncellas, Barranco Maro, Huerto Romero, and Maro Beach with an average of $446 \pm$ 
$70750 \mathrm{mmol} \mathrm{m}^{-3}(\mathrm{n}=6)$. Water samples that were directly derived from Maro Spring (Maro spring, 708 Maro Creek) and did not experience infiltration (i.e. had no fertilizer added), showed $\mathrm{NO}_{3}{ }^{-}$ 709 concentration of $5-21 \mathrm{mmol} \mathrm{m}^{-3} \cdot \mathrm{NO}_{3}{ }^{-}$concentrations in diffuse groundwater seepage in Maro 710 Cliff were consistently near $130 \pm 3 \mathrm{mmol} \mathrm{m}^{-3}(\mathrm{n}=2)$. Samples collected in the schist section 711 from groundwater-fed Miel Creek and coastal spring Alberquillas, and in the karst section from 712 Cantarrijan Beach, showed levels of $\mathrm{NO}_{3}{ }^{-}$ranging from $55 \mathrm{mmol} \mathrm{m}{ }^{-3}$ in Miel Creek to $168 \mathrm{mmol}$ $713 \mathrm{~m}^{-3}$ in Cantarrijan Beach $(\mathrm{n}=5)$ (Supplementary material Table A.2). Nitrate fluxes were unevenly distributed in the three sections of the study site (Table 4).

715 The combination of high $\mathrm{NO}_{3}{ }^{-}$in coastal springs and high flow groundwater seepage results in $716 \mathrm{NO}_{3}{ }^{-}$fluxes in the conglomerate section of $550 \pm 140 \mathrm{~mol} \mathrm{~d}^{-1}$ and $730 \pm 190 \mathrm{~mol} \mathrm{~d}^{-1}$. During this

717 study, $\mathrm{NO}_{3}{ }^{-}$fluxes in the schist and karst section together were $150 \pm 20 \mathrm{~mol} \mathrm{~d}^{-1}$ during dry and $718250 \pm 40 \mathrm{~mol} \mathrm{~d}^{-1}$ during wet periods (Table 4).

5 Discussion

\subsection{Method selection and assessment of each form of groundwater discharge to the}

722 sea

724 found to be the most difficult part of this study. None of the data collected during the three ${ }^{222} \mathrm{Rn}$ 725 boat surveys along the coastline showed tracer anomalies in the areas of submarine spring 726 discharge (Fig. 5). However, we were able to detect ${ }^{224}$ Ra and salinity anomalies produced by the 727 three submarine springs discharging from Cantarrijan, Palomas, and Sifon Caves (Fig. 3 and 4). 728 Concentrations of ${ }^{224}$ Ra were on average four times higher $\left(20 \pm 7 \mathrm{dpm} \mathrm{m}^{-3}, \mathrm{n}=10\right)$ compared to 729 offshore waters $\left(8 \pm 1 \mathrm{dpm} \mathrm{m}^{-3}, \mathrm{n}=4\right)$ in locations where no ${ }^{222} \mathrm{Rn}$ signal was detected. 
Considering that ${ }^{224} \mathrm{Ra}$ and ${ }^{222} \mathrm{Rn}$ have similar half-lives and experience similar mixing,

731 we hypothesize that the lower ${ }^{222} \mathrm{Rn}$ concentrations in coastal waters of the karst section must be

732 due to degassing. Similar effects on dissolved ${ }^{222} \mathrm{Rn}$ and ${ }^{224} \mathrm{Ra}$ have been observed in coastal

733 waters by Dulaiova and Burnett (2006) and Stieglitz et al. (2010). As found in this study site,

734 both studies showed a strong correlation between ${ }^{222} \mathrm{Rn}$ concentration and salinity or ${ }^{222} \mathrm{Rn}$

735 and ${ }^{224} \mathrm{Ra}$, trends that are consistent with a ${ }^{222} \mathrm{Rn}$ deficiency due to atmospheric evasion (Stieglitz

736 et al, 2010). Furthermore, when combining the ${ }^{222} \mathrm{Rn}$ concentration data with salinity anomalies

737 from all boat surveys along the entire shoreline, we observe that ${ }^{222} \mathrm{Rn}$ concentrations decrease at

738 a faster rate than salinity when closer to the groundwater source (Fig. 9a, b). If wind conditions

739 are constant during the surveys (which there were), following the $1^{\text {st }}$ Fick's Law, degassing due

740 to molecular diffusion through the water-atmosphere interphase must be enhanced when

741 seawater ${ }^{222} \mathrm{Rn}$ concentration is higher (the concentration gradient is higher). Thus, this effect is

742 most likely created because the water column-atmosphere concentration gradient in areas close

743 to the groundwater source is at its highest, favoring atmospheric evasion.

745 Figure 9: Mixing plots of ${ }^{224} \mathrm{Ra}(\mathrm{a})$ and ${ }^{222} \mathrm{Rn}$ versus salinity (b) showing best fit linear and 746 exponential mixing lines, respectively, during surface water surveys along the coastline in 747 September of 2010, July and December of 2015. balances are the two methods better suited to evaluate groundwater discharge from submarine 751 springs of the ones utilized in this study. However, we found a significant difference between the 752 springs discharge assessments obtained using these two tracers; the flux based on the ${ }^{224} \mathrm{Ra}$ mass 753 balance was $12.8 \pm 1.4 \times 10^{3} \mathrm{~m}^{3} \mathrm{~d}^{-1}$, whereas using the salinity mass balance we calculated a 
754 discharge of $2.3 \pm 0.2 \times 10^{3} \mathrm{~m}^{3} \mathrm{~d}^{-1}$. We suggest that the difference could be explained by 755 selection of the end-member in the mixing model, which has been previously described by others 756 as a factor in correct determination of groundwater discharge (e.g. Peterson et al., 2008; Moore, 757 1996; Cerdà-Domènech et al., 2017). A critical component in any tracer study is the selection of 758 a representative groundwater end-member $\left(R a_{S G D}\right.$ and $\left.S a l_{S G D}\right)$ collected at the point of discharge. Palomas, and Sifon Caves) with vents parallel to the surface (i.e. horizontal geometry) at depths of $8-15 \mathrm{~m}$ below sea level. The springs discharge occurs parallel to the land surface at about 5 $76210 \mathrm{~m}$ landward from the caves entrance. SCUBA diving to the springs vents for representative 763 groundwater/spring water end-member was challenging, thus the presented estimates of spring 764 discharge are based on groundwater from the closest located well (GW-CG-1, Fig. 1) with $765 \quad \mathrm{a}^{224} \mathrm{Ra}$ concentration of $1260 \pm 90 \mathrm{dpm} \mathrm{m}^{-3}$ and salinity of $2.2 \pm 0.1$. Because springs conduits are subject to seawater intrusion, we suggest that the salinity of 767 the discharging spring water could be slightly to significantly higher than groundwater salinity 768 sampled from the inland well (GW-CG-1) which we used as the groundwater end-member $769\left(R a_{S G D}\right.$ and $\left.S a l_{S G D}\right)$. While in fresh water, radium is mostly attached to particles and its dissolved 770 concentration is very low, in brackish spring water radium would be mostly dissolved and we 771 would have observed higher ${ }^{224} \mathrm{Ra}$ in the end-member waters (Burnett et al., 2006; Cerdà772 Domènech et al., 2017). Based on the correlation between salinity and ${ }^{224}$ Ra desorption, a 773 salinity increase of 5 to the groundwater end-member (GW-CG-1) would produce an 774 extrapolated ${ }^{224} \mathrm{Ra}$ increase of $60 \mathrm{dpm} \mathrm{m}{ }^{-3}$, resulting in a decrease spring flux of about $65 \%$, 775 which is closer to the salinity mass balance estimation. A salinity of 5 in submarine springs 776 seems reasonable as it is similar to those found by García-Solsona et al. (2010) in a coastal karst 
777 aquifer in eastern Spain, where annual average salinity of outflowing brackish submarine springs

778 was 6.8. Furthermore, in well GW-CG-1 located $500 \mathrm{~m}$ inland from the submarine springs in the

779 karstic marble, a salinity value of 2.2 was measured, also indicating that a value of 5 was 780 plausible.

781

The salinity mass balance method estimates only the fresh water fraction of the spring

782 discharge. In this way, the difference in discharge estimation using a ${ }^{224} \mathrm{Ra}$ and a salinity mass

783 balance is found because the ${ }^{224} \mathrm{Ra}$ method estimates the total (brackish) discharge, while the

784 salinity method accounts only for the fresh portion. Therefore, only the spring discharge based

785 on the salinity model should be used in the water budget of Sierra Almijara-Alberquillas Aquifer.

Diffuse groundwater seepage through seabed sediments: In contrast to the case of

787 submarine spring discharge, we found that groundwater seepage through seabed sediments

788 (Maro Cliff, conglomerate section; and Cantarrijan Beach, karst section) was most adequately

789 detectable using ${ }^{222} \mathrm{Rn}$ as a tracer and direct measurements (i.e. seepage meters). The 790 observed ${ }^{222} \mathrm{Rn}$ concentrations in receiving surface waters were as high as $44 \pm 3 \times 10^{3} \mathrm{dpm} \mathrm{m}^{-3}$ 791 at both groundwater seepage areas, i.e. Maro Cliff and Cantarrijan Beach (Fig. 4).

792 Although, we also observed high ${ }^{224} \mathrm{Ra}$ concentrations in samples collected near 793 Cantarrijan Beach (Fig. 3), these were associated with nearby discharge from the Cantarrijan 794 Caves submarine spring (Fig. 3, sampling points SW-6, SW-7, and SW-13). Indeed, during one 795 of the dry period sampling events (July of 2016), we did not detect any ${ }^{224} \mathrm{Rn}$ in coastal waters of 796 Cantarrijan Beach giving us confidence that the previously observed signals (September 2010) 797 were from the springs and not from the diffuse seepage. For the same reason, salinity could not 798 be used as a tracer in either of the seepage areas (Maro Cliff and Cantarrijan Beach) because 
salinity anomalies were also created mostly by nearby coastal and submarine springs respectively, overwhelming the salinity signal that is only due to diffuse seepage.

In this complex scenario, ${ }^{222} \mathrm{Rn}$ was the only groundwater tracer able to uniquely identify diffuse groundwater seepage to the sea and a ${ }^{222} \mathrm{Rn}$ mass balance was thus used to quantify groundwater seepage fluxes. Based on this mass balance in the Maro Cliff area, we calculated a discharge of $2.9 \pm 0.8 \times 10^{3} \mathrm{~m}^{3} \mathrm{~d}^{-1}$ (Table 2), whereas using seepage meter deployments $(\mathrm{n}=4)$ the discharge was $2.1 \pm 0.4 \times 10^{3} \mathrm{~m}^{3} \mathrm{~d}^{-1}$. In the Cantarrijan Beach we found very similar seepage flux estimates using the ${ }^{222} \mathrm{Rn}$ approach $\left(0.9 \pm 0.1 \times 10^{3} \mathrm{~m}^{3} \mathrm{~d}^{-1}\right)$ and using seepage meters $(0.8 \pm$ $0.2 \times 10^{3} \mathrm{~m}^{3} \mathrm{~d}^{-1}$ ) with a total of 9 deployments (Table 2). While the two methods agree very well, we recommend using the ${ }^{222} \mathrm{Rn}$ method over seepage meters. The main advantages of the ${ }^{222} \mathrm{Rn}$ technique are (1) fully automatic data collection with very little field efforts, (2) temporal and spatially integrated SGD estimates, which allow capturing small hydraulic conductivity variations over large areas of diffuse seepage (Burnett et al., 2001).

Subaerial forms of groundwater discharge to the sea (coastal springs and groundwaterfed creeks): Coastal springs, and creeks that are primarily groundwater sustained, were only present at the conglomerate and schist sections of the study site that are comprised of conglomerate and schist, where permeablities are lower than in the marble formation (karst section). During boat surveys ${ }^{222} \mathrm{Rn}$ activity levels in coastal waters of these two sections were always within background offshore values $\left(1.0 \pm 0.2 \times 10^{3} \mathrm{dpm} \mathrm{m}^{-3}\right.$, Fig. 5) even at the points of coastal springs and groundwater-fed creeks discharge that were visually identified. We attributed the observed low ${ }^{222} \mathrm{Rn}$ concentrations to degassing and radioactive decay during groundwater transit from land to the ocean. For instance, ${ }^{222} \mathrm{Rn}$ concentration at the point of the groundwaterfed Maro Creek origin (Maro Spring, $250 \pm 90 \mathrm{dpm} \mathrm{m}^{-3}$ ) was significantly higher than at the 
822 point of the Creek entrance to the sea (Maro Creek 3, $16 \pm 7 \mathrm{dpm} \mathrm{m}^{-3}$ ) (Fig. 1; Supplementary 823 material Table A.2). However, we were able to find groundwater signature of the Miel Creek and

824 the Alberquillas coastal spring in coastal waters of the schist section using ${ }^{224}$ Ra concentration 825 anomalies; radium was $56 \pm 4 \mathrm{dpm} \mathrm{m}^{-3}$ and $12 \pm 2 \mathrm{dpm} \mathrm{m}^{-3}$ respectively at their point of entry to 826 the sea (Fig. 1). While coastal springs were easily located visually, additional field efforts were 827 usually required to determine whether the creeks were solely fed by groundwater inputs from the 828 karst aquifer in order to be considered (or not) in the total groundwater budget of Sierra 829 Almijara-Alberquillas Aquifer.

Total groundwater discharge to Maro-Cerro Gordo coastal area: Combining all groundwater fluxes to the sea in Maro-Cerro Gordo, we estimate a daily groundwater discharge

832 that ranged between $9 \pm 2 \times 10^{3} \mathrm{~m}^{3} \mathrm{~d}^{-1}$ during dry periods and $12 \pm 3 \times 10^{3} \mathrm{~m}^{3} \mathrm{~d}^{-1}$ during wet 833 periods, with an average of $11 \pm 3 \times 10^{3} \mathrm{~m}^{3} \mathrm{~d}^{-1}$. This combined discharge is composed of: $3.6-$ $8344.0 \times 10^{3} \mathrm{~m}^{3} \mathrm{~d}^{-1}$ in the conglomerate section, $2.4-3.6 \times 10^{3} \mathrm{~m}^{3} \mathrm{~d}^{-1}$ in the schist section , and $3.3-$ 835 $4.7 \times 10^{3} \mathrm{~m}^{3} \mathrm{~d}^{-1}$ in the karst section (Supplementary material Table A.2). As described above, differences in the geologic settings in each section, have defined the form of groundwater flow to the sea (Fig. 10, Table 4).

Figure 10: Total groundwater discharge (TGD) in the study area divided in forms of discharge (GS: groundwater diffuse seepage, CS: coastal springs, GC: groundwater-fed creeks, SS: submarine springs), showing maximum and minimum flux during wet and dry periods. in the study area, whereas small coastal springs dispersed along the section contribute to $5-6 \%$, 
846 and groundwater-fed creeks for $1-2 \%$. The ubiquitous presence of a schist formation in the

847 schist section impedes direct submarine flow and groundwater discharge converges in two

848 points: groundwater-fed Miel Creek, and Alberquillas coastal spring which account for 25 - 30\%

849 of the total discharge. In the karst section, where Sierra Almijara-Alberquillas Aquifer is in direct

850 connection with the sea, SGD takes place as groundwater seepage through marine sediments in

851 Cantarrijan Beach assessed to account for 10 - 18\%. Karstic submarine springs in Cantarrijan

852 Caves, Palomas Cave, and Sifon Cave represent 19 - 25\% of the total groundwater discharge to

853 the sea.

854

855

5.2 Complexity of Sierra Almijara-Alberquillas karst aquifer hydrodynamics

The large spatial variations in the different forms of groundwater discharge in this coastal

856 karst aquifer were also reflected in the seasonal variability of discharge during contrasting

857 periods (Fig. 2). For instance, in Maro Cliff (conglomerate section, Fig. 1) we expected higher

858 seepage rates in December during the wet period (Fig. 2). However, the discharge estimations for

859 the dry period (July) and the wet period (December) were statistically identical: groundwater

860 seepage in Maro Cliff during the dry period was $2.9 \pm 0.8 \times 10^{3} \mathrm{~m}^{3} \mathrm{~d}^{-1}$ and $3.0 \pm 0.8 \times 10^{3} \mathrm{~m}^{3} \mathrm{~d}^{-}$

$861{ }^{1}$ during the wet period.

862

There are two hypotheses that attempt to explain the observed lack of seasonal variation

863 of groundwater discharge in Maro Cliff. The first hypothesis suggests that the observed steady

864 flow is maintained by continuous infiltration of agricultural irrigation water used by the adjacent

865 greenhouse fields. A second hypothesis, proposed by Espejo et al. (1988) and Castillo et al.

866 (2001) suggests that the surplus of groundwater that maintains the base flow during the dry

867 season originates from the Sierra Almijara-Alberquillas Aquifer. The authors propose that

868 groundwater is transferred from the Sierra Almijara-Alberquillas Aquifer to the coast through the 
869 adjacent conglomerate unit and travertines near the small town of Maro. These two

870 hydrogeologic units are indeed in immidate contact with the sea (Fig. 1).To test both hypotheses

871 we used two common geochemical approaches.

872 We first differentiated between heavier isotopic $\left(\delta^{2} \mathrm{H}\right.$ and $\left.\delta^{18} \mathrm{O}\right)$ compositions (more 873 positive values), associated with evaporation processes or mixing with seawater (Gat, 1971). The 874 isotopic composition of groundwater collected from Maro Spring (i.e. in the conglomerate 875 section) showed the most negative values (-46\%, $-7.7 \%$ o) on the local groundwater line (LWL) in 876 this area (Fig. 8b). These values correspond to the composition of deep groundwater flow in 877 Sierra Almijara-Alberquillas Aquifer (Liñán et al., 2000). Groundwater seepage in Maro Cliff 878 presents average isotopic values (-44\%o and -7.4\%o) that are similar but slightly higher than Maro 879 Spring, suggesting that water transfer from the marble formation is a plausible option.

881 Alberquillas Aquifer to the travertines, the water stable isotopes end-members have to be very 882 different than the deep/spring groundwater which has a negative composition compared to more 883 positive values of evaporated irrigation water. We know that the water used for irrigation is 884 withdrawn by farmers from Maro Spring. However, once extracted and in contact with the 885 atmosphere, the water isotopic composition changes to more positive isotopic values. We also 886 found that the collected spring water utilized for irrigation is typically stored in holding tanks 887 and used when needed. During this holding time and in the process of irrigation, the water 888 experiences further evaporation, and as a result, it should result in even more positive isotopic 889 signature such us the waters of the coastal spring Barranco Maro (up to -43 and -7.3 ). The 890 isotopic signature of irrigation water is thus, very different from the original Maro Spring water, 891 allowing us to define a two-end-member system where coastal spring Huerto Romero represents 
892 the most evaporated irrigation water (Fig. 8b). Based on a mixing model using these end893 members we found that seeping groundwater at Maro Cliff is indeed composed mostly from 894 infiltrating irrigation water. We also found that the ratio of Maro Spring water to irrigation 895 changes depending on the season with highest percentage (up to 82\%) of irrigation water during 896 the dry period compared to the wet period (74\%).

To further confirm these finding, we utilized water quality parameters, such as sulfate $898\left(\mathrm{SO}_{4}{ }^{2-}\right)$ and nitrate $\left(\mathrm{NO}_{3}{ }^{-}\right)$concentrations, to differentiate between these two water sources. 899 Infiltrated irrigation water should have much higher $\mathrm{NO}_{3}{ }^{-}$concentrations and constant $\mathrm{SO}_{4}{ }^{2-}$, 900 whereas deep groundwater should natural concentrations of $\mathrm{NO}_{3}{ }^{-}$. Thus, $\mathrm{NO}_{3}{ }^{-}$content can be 901 used as an indication of irrigation origin. The isotopic composition of Sierra Almijara902 Alberquillas Aquifer in this area fall within a narrow $\mathrm{SO}_{4}{ }^{2-}$ concentration range $(1700-2600$ 903 mmol m³ ) (Fig. 11), being naturally high in Maro Spring groundwater (Liñán et al., 2000). 904 When plotting $\mathrm{SO}_{4}{ }^{2-}$ and $\mathrm{NO}_{3}{ }^{-}$concentrations in water, all water samples derived from Maro 905 Spring before infiltration showed low $\mathrm{NO}_{3}{ }^{-}$concentration $\left(5-21 \mathrm{mmol} \mathrm{m}^{-3}\right)$ and naturally high 906 levels of $\mathrm{SO}_{4}{ }^{2-}$ (Fig. 11). All samples collected from coastal springs that discharge to the sea 907 (Doncellas, Barranco Maro, Huerto Romero, and Maro Beach coastal springs), showed levels of $908 \mathrm{SO}_{4}{ }^{-2}$ typical of Sierra Almijara-Alberquillas Aquifer and high levels of $\mathrm{NO}_{3}{ }^{-}$(more than 350 $909 \mathrm{mmol} \mathrm{m}{ }^{-3}$ ) indicating fertilizer inputs. On the other hand, samples collected at the area of 910 seepage through seabed sediments in the Maro Cliff, showed $\mathrm{NO}_{3}{ }^{-}$concentrations $\left(130 \mathrm{mmol} \mathrm{m}^{-}\right.$

$913^{3}$ ) that are closer to the observed background levels of Sierra Almijara-Alberquillas groundwater 912 representative $\left(5-21 \mathrm{mmol} \mathrm{m}^{-3}\right)$ than to the contaminated infiltrated water (Fig. 11).

914 Figure 11: Groundwater ionic relationship between $\mathrm{NO}_{3}{ }^{-}$and $\mathrm{SO}_{4}{ }^{2-}$ where groundwater samples 915 with similar composition are grouped in dashed squares. Symbols are presented as in Fig. 8 based 
on the section and lithology they are located. In the conglomerate section Maro Spring, Nerja Cave,

917 and Maro Creek show similar $\mathrm{SO}_{4}{ }^{2-}$ concentration with low $\mathrm{NO}_{3}{ }^{-}$, while Doncellas, Barranco Maro,

918 Huerto Romero, and Maro Beach present $\mathrm{NO}_{3}{ }^{-}$contamination. Samples from the schist section

919 (Miel and Alberquillas) present a distinctive signal with $\mathrm{low} \mathrm{NO}_{3}{ }^{-}$and $\mathrm{SO}_{4}{ }^{2-}$ concentrations.

920 Groundwater collected in Cantarrijan Beach (karst section) shows seawater influence from

921 saltwater recirculation in beach sediments. Arrows indicate the geochemical change before

922 irrigation and after fertilizers application $\left(\mathrm{NO}_{3}{ }^{-}\right)$, where Maro cliff (diffuse seepage) shows mixing

923 between both groups.

924

925

Therefore, we are confident that groundwater seepage to the sea observed and quantified

926 in Maro Cliff is mostly generated as a result of infiltrated irrigation water. We found uniform

927 groundwater flux (independently of rainfall) in this area throughout the year (Fig. 6a) supporting

928 this hypothesis. Irrigation occurs constantly throughout the year, and infiltration through the

929 highly porous travertine constitutes a constant source of water that flows towards the coast and

930 ultimately discharges into the sea as groundwater seepage. Irrigation water from greenhouse

931 farming is collected from the Maro Spring and thus SGD in the Maro Cliff should not be added

932 to the total budget of the aquifer system as it has been already accounted as groundwater from

933 Maro Spring on land. This is a significant new finding and should be considered when compiling

934 the total water budget of the Sierra Almijara-Alberquillas Aquifer.

935 In contrast to the groundwater seepage dynamics in Maro Cliff (conglomerate section),

936 the seepage rates in the Cantarrijan Beach (karst section) were seasonally modulated; the

937 groundwater flux that the Cantarrijan Beach area received in the dry period was $0.9 \pm 0.1 \times$

$93810^{3} \mathrm{~m}^{3} \mathrm{~d}^{-1}$ which was half of its wet period discharge $\left(2.3 \pm 0.3 \times 10^{3} \mathrm{~m}^{3} \mathrm{~d}^{-1}\right)$. Differences in

939 aquifer recharge and sea level variations between the dry and wet periods have control on the 
940

941

942

943

944

945

946

947

948

949

950

951

952

953

954

955

956

957

958

959

960

961

962

magnitude of SGD (Carrasco et al, 1998; Santos et al., 2009). During dry periods precipitation was absent for up to two months, decreasing the recharge from infiltrated meteoric water in Sierra Almijara-Alberquillas Aquifer. Although during December of 2015 the area did not receive any rainfall, rain events occurred during September-November contributed to the recharge of Sierra Almijara-Alberquillas Aquifer, deriving in higher seepage fluxes in Cantarrijan Beach (Fig. 2). Additionally, the mean sea level measured during 2010-2016 near the study area (Permanent Service for Mean Sea Level, http://www.psmsl.org/data/obtaining/stations/1940.php) showed seasonal fluctuations, with lower sea levels during January-May compared to higher levels during August-December (Fig. 2). The observed moderate increase of $15 \mathrm{~cm}$ during the dry periods has contributed to the observed higher salinity of groundwater in Cantarrijan Beach, as well as the overall lower groundwater seepage rates during the dry periods.

Based on the salinity mixing model (Eqs. 9 and 10), we calculated that the fresh fraction of SGD was $48 \%$ of the total groundwater seepage, which means that during July of 2016, only $0.4 \pm 0.1 \times 10^{3} \mathrm{~m}^{3} \mathrm{~d}^{-1}$ should be taken into account as part of the Sierra Almijara-Alberquillas Aquifer water budget.

The salinity gradient observed from GW-Well to GW-Pz-4 is an indication that there is saltwater recirculation in the beach sediments and with the ${ }^{222} \mathrm{Rn}$ approach we have captured both the fresh and recirculated SGD (Fig. 6c). We did not repeat these measurements during the wet period, but we can hypothesize that this percentage was very similar based on the salinity measured in GW-Well during December of 2015 (Supplementary material Table A.2).

5.3 Importance of groundwater discharge for the water budget of Sierra AlmijaraAlberquillas Aquifer and nitrate loading to Maro-Cerro Gordo coastal area 
To estimate the portion of the annual fresh groundwater discharge to the sea from Sierra

964 Almijara-Alberquillas Aquifer water budget, we extrapolated average daily fluxes to obtain an

965 annual range for the wet and dry periods (Table 4). During this study, we found that the total

966 groundwater discharge to the sea was $1.9 \pm 0.5 \times 10^{6} \mathrm{~m}^{3} \mathrm{y}^{-1}$ during the dry period, and $2.6 \pm 0.8 \times$

$96710^{6} \mathrm{~m}^{3} \mathrm{y}^{-1}$ wet period (Table 4). Based on Pérez-Ramos and Andreo (2007) and Castillo et al.

968 (2001) the total annual groundwater budget of the Sierra Almijara-Alberquillas Aquifer is $50 \times$

$96910^{6} \mathrm{~m}^{3} \mathrm{y}^{-1}$, and thus the flux we estimated represents $4-5 \%$ of the water resources of this karst

970 system. This is a conservative estimate and should be considered as groundwater flow at base

971 conditions because sampling campaigns were purposely not conducted after big rain events (Fig.

972 2).

973 In these calculations, we do not account for groundwater seepage in Maro Cliff

974 (conglomerate section), coastal springs Doncellas, Barranco Maro, Huerto Romero, and Maro

975 Beach, and groundwater-fed Tierras Nuevas Creek as they are originated from irrigation water 976 that has been already accounted as outputs from Maro Spring.

Based on the groundwater discharge to the sea, $\mathrm{NO}_{3}{ }^{-}$fluxes per unit of shore length in the 978 conglomerate section were $205 \pm 90 \mathrm{mmol} \mathrm{m}^{-1} \mathrm{~d}^{-1}$, while the schist and karst sections together 979 receive between $15 \pm 3 \mathrm{mmol} \mathrm{m}^{-1} \mathrm{~d}^{-1}$ on average. When normalized by shore length, $\mathrm{NO}_{3}{ }^{-}$ 980 discharge in the conglomerate section is $3.5 \mathrm{mmol} \mathrm{m}^{-2} \mathrm{~d}^{-}$, which compared to other 981 anthropogenically impacted sites of coastal karst aquifers in the Mediterranean, is very similar.

982 For example, García-Solsona et al. (2010) estimated a nitrate flux of $8.3-1.5 \mathrm{mmol} \mathrm{m}^{-2} \mathrm{~d}^{-1}$ in 983 eastern Spain, and Rodellas et al. (2014) found $0.97 \mathrm{mmol} \mathrm{m}^{-2} \mathrm{~d}^{-1}$ in Majorca Island (Balearic 984 Islands), whereas in a site in Menorca Island the flux was $18 \mathrm{mmol} \mathrm{m}^{-2} \mathrm{~d}^{-1}$ (García-Solsona et al., 985 2010b). It is important to note that while it only represents $20 \%$ (or $3 \mathrm{~km}$ ) of the total shoreline 
986 length $(16 \mathrm{~km})$, the conglomerate section receives about $75 \%$ of the total $\mathrm{NO}_{3}{ }^{-}$delivered to 987 Maro-Cerro Gordo coastal waters (Supplementary material Table A.2).

Since 1989 the Maro-Cerro Gordo Natural Area (schist and karst sections), has been 989 protected due to the presence of endemic and endangered flora and fauna by the Council of 990 Environment of Andalusia. The European Commission designated the area as a Special 991 Protection Area (SPA), Specially Protected Area of Mediterranean Importance (SPAMI), Site of 992 Community Importance (SCI), and Special Area of Conservation (SAC) (Aranda and Otero, 993 2014). Specifically, the conservation area hosts three species of marine phanerogams (Zostera 994 marina, Posidonia oceanica, and Cymodocea nodosa), included in the IUCN Red List of 995 Threatened Species. Seagrass provides a unique habitat for a wide range of species (Hughes et 996 al., 2009); including the largest bivalve in the Mediterranean Pinna nobilis (Theodorou et al., 997 2015), endangered fish Epinephelus marginatus (Gallego et al., 2015), and marine turtle Caretta 998 caretta (Tomas et al., 2001) among others. As other studies have demonstrated, nitrate surplus 999 loading often alters the primary producers community (Rapport and Whitford, 1999), and fast 1000 growing micro and macroalgae can proliferate preventing seagrasses Zostera marina and 1001 Posidonia oceanica from having enough sunlight and space (Hauxwell et al., 2001; Deegan et 1002 al., 2002). For example, Valiela et al. (2002) demonstrated that seagrass production could 1003 decrease up to $90 \%$ when nitrogen inputs are higher than $500 \mathrm{~kg} \mathrm{~N} \mathrm{ha}^{-1} \mathrm{y}^{-1}$. Only in the 1004 groundwater seepage area of Maro Cliff we have found that nitrogen fluxes (as nitrate) was 1005 about $2500 \mathrm{~kg} \mathrm{~N} \mathrm{ha}^{-1} \mathrm{y}^{-1}$, which is five times higher than the Valiela et al.'s assessment and 1006 should be a major concern for the ecological status of the marine system in the conglomerate 1007 section (Fig. 1). However, to further understand the implications of nutrients fluxes to the sea on 
1008 the marine ecosystem (particularly on endemic seagrass and fauna), additional investigation in 1009 the area must be conducted.

1010

1011

1012

1013

1014

1015

1016

1017

1018

1019

1020

1021

1022

1023

1024

1025

1026

1027

1028

1029

1030

\subsection{Sensitivity analysis of methods applied}

To further compare the applicability of methodologies utilized in the presented multimethod approach, we constructed a sensitivity analysis including each method's main assumptions.

\subsubsection{Parameter sensitivity of ${ }^{224} \mathrm{Ra}$ and salinity mass balance methods for} determining discharge of submarine springs

Three terms represent the major source of uncertainty in the ${ }^{224} \mathrm{Ra}$ and salinity mass balances we used to calculate submarine spring discharge, including (1) the residence time of the receiving coastal waters $(t)$, (2) the volume of the SGD plume (V), and (3) the uncertainty in the determination of groundwater end-member $\left(R a_{S G D}\right)$ (Table 5).

The largest uncertainty in this model is given by the assumption of a one day residence time $(t)$. A common technique for assessing water ages of coastal waters is based on short-lived radium isotopes, ${ }^{223} \mathrm{Ra}$ and ${ }^{224} \mathrm{Ra}$ (Moore, 2000). However, during this study we could not measure both radium isotopes and we were unable to apply this method. The karst section of Maro-Cerro Gordo displays rocky cliff areas spread across the geographically exposed to prevailing west winds coastline which reflects the influence of high energy waves. The karst aquifer has very high secondary porosity and permeability which provides the opportunity for extensive groundwater-surface water exchange. The estimate of a one day residence time for this study is based on a comparison to similar high-energy coastal environments that are typical for the Mediterranean coastline. Under similar hydrogeological conditions in eastern Spain, using the methodology presented in Moore (2000), García-Solsona et al. (2010) assessed residence 
1031 time $(t)$ between $1.1 \mathrm{~d}$ and 2.7 d, whereas Tovar-Sánchez et al. (2014) found residence times of 1032 1.7, and 1.2 days in three coves in a karst system in the eastern shore of the Majorca Island. 1033 Considering these studies and specifics of this study site, we suggest using residence times of $10340.25,0.5,1.0$, and 3.0 days in the sensitivity analysis. To determine the volume $(\mathrm{V}=$ plume area $\times$ depth) of the SGD plume, we used areas of 1036 salinity sea surface anomalies created by the submarine springs discharge at Maro-Cerro Gordo. 1037 Specifically, we utilized salinity anomalies of $-0.3,0.0,0.3$, and 0.6 isolines. For vertical scale 1038 we use water depths acquired from the bathymetry database of the Andalusia Council of 1039 Environment (http://www.juntadeandalucia.es/medioambiente/site/rediam) assuming a well1040 mixed water column. However, Garcia-Solsona et al. (2010) found in eastern Spain that although 1041 complete mixing in the water column could be found near the karst springs vents, the salinity 1042 anomaly measured in surface waters was limited to the $0.5 \mathrm{~m}$ upper most layer. Similar settings 1043 are possible in Maro-Cerro Gordo; thus, we also calculated $V$ based on the 0.0 salinity anomaly 1044 isoline and considering a depth of $0.5 \mathrm{~m}$ (Table 5)

1045 There are only two groundwater wells in the karst section of Maro-Cerro Gordo, (GW1046 CG-1 and GW-CG-2). For the sensitivity analysis we used ${ }^{224}$ Ra concentration in GW-CG-1

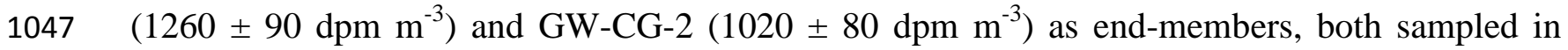
1048 September of 2006.

1049 After tabulating these parameters, both the ${ }^{224} \mathrm{Ra}$ and salinity mass balance models 1050 showed the highest sensitivity to variations in the volume affected by SGD (V). We found that 1051 the total discharge from submarine springs decreases by $80 \%$ when using salinity isolines of 0.6 1052 to -0.3 in a well-mixed water column; however, if the fresh plume is limited to the $0.5 \mathrm{~m}$ top 1053 layer of the water column, the decrease is up to $97 \%$. Residence time $(t)$ was the second most 
1054 important variable affecting the variability of discharge from submarine springs, increasing by $105592 \%$ when changing the residence time from 0.25 to 3.0 days (Table 5). The ${ }^{224} \mathrm{Ra}$ mass balance 1056 showed limited sensitivity to varying groundwater end-member values $\left(R a_{S G D}\right)$, when using the 1057 GW-CG-2 value instead of GW-CG-1, all estimations increased only by $20 \%$. The maximum 1058 variation utilizing the three variables simultaneously in the ${ }^{224} \mathrm{Ra}$ mass balance was $100 \%$ with a 1059 total discharge of $0.2-90.5 \times 10^{3} \mathrm{~m}^{3} \mathrm{~d}^{-1}$. The salinity mass balance presented a total variation of $1060100 \%$ to changing $t$ and $V$, with a total discharge of $0.03-13.5 \times 10^{3} \mathrm{~m}^{3} \mathrm{~d}^{-1}$, which represents 1061 the purely fresh discharge (Table 5).

\subsubsection{Parameter sensitivity of the ${ }^{222} \mathrm{Rn}$ mass balance and seepage meters} measurements in determining diffuse seepage

In the ${ }^{222} \mathrm{Rn}$ model, we considered that only the seepage area $(A)$ could be subject to ambiguity because all terms in the model (including the groundwater end-member) have been carefully measured. To delineate the size of the seepage face we used the following ${ }^{222} \mathrm{Rn}$ 1067 concentration isolines: for the Cantarrijan Beach we used the 10, 8, 6, and $5 \mathrm{dpm} \mathrm{m}^{-3}$, while in 1068 Maro Cliff we used the 25, 30, 35, and $45 \mathrm{dpm} \mathrm{m}^{-3}$ (Table 5). For comparison reasons, were used 1069 the same seepage areas to calculate SGD when using the seepage meters approach. Using the 25 $1070 \times 10^{3} \mathrm{dpm} \mathrm{m}^{-3222} \mathrm{Rn}$ concentration isoline in Maro Cliff produces $86 \%$ higher for both dry and 1071 wet periods, compared to seepage area based on the $45 \times 10^{3} \mathrm{dpm} \mathrm{m}^{-3}$ isoline. The discharge 1072 ranged from $0.9-6.7 \times 10^{3} \mathrm{~m}^{3} \mathrm{~d}^{-1}$ and $0.9-7.5 \times 10^{3} \mathrm{~m}^{3} \mathrm{~d}^{-1}$ during dry and wet periods 1073 respectively. In Cantarrijan Beach we found an increase of 82\%, with a discharge estimation that 1074 ranged between $0.2-1.2 \times 10^{3} \mathrm{~m}^{3} \mathrm{~d}^{-1}$ and $0.5-2.9 \times 10^{3} \mathrm{~m}^{3} \mathrm{~d}^{-1}$ during dry and wet periods. The 1075 radon method showed higher sensitivity (89\%) than the seepage meter assessments (87\%) (Table 1076 5). 


\section{Aquifer}

Using the presented ranges of fluxes of each methodology, we calculated a total 1080 groundwater discharge to the sea of $4.3-105.1 \times 10^{3} \mathrm{~m}^{3} \mathrm{~d}^{-1}$ from all forms of discharge (Table 1081 6). The fresh water component of the total discharge can be obtained from the salinity mass 1082 balance in submarine springs, ${ }^{222} \mathrm{Rn}$ mass balance and seepage meters for diffuse seepage in 1083 Cantarrijan Beach (47\% fresh, based on the salinity mixing model), Caleta and Miel Creeks, and 1084 Alberquillas Spring (see sections 5.2 and 5.3). Applying a residence time of $0.25 \mathrm{~d}$, the lowest 1085 estimated volumes affected by the SGD plume $(V)$ at each submarine spring $\left(0.2 \times 10^{5} \mathrm{~m}^{3}, 0.18\right.$ $1086 \times 10^{5} \mathrm{~m}^{3}, 0.19 \times 10^{5} \mathrm{~m}^{3}$ ) derived from a $0.5 \mathrm{~m}$ water column, and the largest estimates for 1087 seepage face in Cantarrijan Beach $\left(\mathrm{A}=1.0 \times 10^{3} \mathrm{~m}^{2}\right)$ for the ${ }^{222} \mathrm{Rn}$ model and seepage meter 1088 methods, the minimum fresh groundwater discharge is $0.9 \times 10^{6} \mathrm{~m}^{3} \mathrm{y}^{-1}$. Applying the assumption 1089 of a 3-days residence time, the largest $V$ at each submarine spring $\left(4.6 \times 10^{5} \mathrm{~m}^{3}, 8.7 \times 10^{5} \mathrm{~m}^{3}\right.$, $\left.10907.1 \times 10^{5} \mathrm{~m}^{3}\right)$, and the largest $A$ in cantarrijan Beach $\left(5.7 \times 10^{3} \mathrm{~m}^{2}\right)$ for the ${ }^{222} \mathrm{Rn}$ model and 1091 seepage meter methods, the maximum fresh groundwater discharge from Sierra Almijara1092 Alberquillas Aquifer is $6.8 \times 10^{6} \mathrm{~m}^{3} \mathrm{y}^{-1}$. A total groundwater discharge of $6.8 \times 10^{6} \mathrm{~m}^{3} \mathrm{y}^{-1}$ seems 1093 plausible but unlikely during base flow conditions when compared to the total water budget of 1094 Sierra Almijara-Alberquillas $\left(50 \times 10^{6} \mathrm{~m}^{3} \mathrm{y}^{-1}\right)$. However, a residence time of 1 day seems more 1095 realistic based on other studies conducted in similar areas. The application of this sensitivity 1096 analysis including all terms and applying a 1-day residence time gives a total discharge of 1.0 $10973.5 \times 10^{6} \mathrm{~m}^{3} \mathrm{y}^{-1}$. 

areas worldwide independent of climate. About half of the Mediterranean and Adriatic coastline 1101 is comprised of karst aquifers and hydrogeological settings similar to Maro-Cerro Gordo can be expected (Fleury et al., 2007, 2005; Surić et al., 2015). In most scenarios authors often point out 1103 that groundwater discharge was not quantified due to the complex settings where at least two 1104 forms of discharge occur in multiple locations (e.g. Fleury et al., 2007; Burnett et al., 2008). 1105 Similar problems are encountered in karst coastlines in the Yucatan Peninsula (Mexico), a karst 1106 platform located in the Caribbean Sea. Gonneea et al. (2014) assumed that submarine springs 1107 were representative of the total SGD in the study area, but pointed out that diffuse discharge 1108 away from springs was not measured. Null et al. (2014) assessed SGD in the eastern shore of the 1109 Yucatan Peninsula where submarine springs and diffuse seepage are present. Due to the lack of a 1110 field method to quantify groundwater seepage, they used analytical calculations to establish a

1111 first order approximation of SGD. Furthermore, SGD in volcanic systems, although geologically 1112 different than karst, have comparable dynamics due to the similar intrinsic porosity and 1113 permeability (Burnett et al, 2008; Johnson et al., 2008; Peterson et al, 2009, Dimova et al, 2012). 1114 Common characteristics of these sites include (1) simultaneous groundwater discharge to 1115 the sea occurring in two or more forms due to highly heterogeneous geological settings, (2) high 1116 infiltration rates resulting in negligible riverine freshwater inputs, and (3) significant 1117 groundwater inputs.

\section{Conclusions}

Work presented here demonstrates that determining total groundwater discharge to the 1121 ocean from coastal karst aquifers is not trivial and it requires a very good understanding of the 
1122 geology and groundwater origin to constrain an adequate water budget. Specifically, as a result

1123 of the complex geology of Maro-Cerro Gordo coastal area and highly heterogeneous Sierra

1124 Almijara-Alberquillas coastal karst aquifer, we found that groundwater discharge manifests in

1125 four different forms: (1) groundwater-fed creeks, (2) coastal springs, (3) groundwater seepage

1126 through seabed sediments, and (4) submarine springs. These expressions of discharge are typical

1127 for karst systems and should be expected in similar geological settings elsewhere including

1128 volcanic systems, which although having different rock composition, behave hydrologically very

1129 similar. We found that only the application of a set of methods specific for each form of

1130 discharge adequately characterizes and gives a realistic evaluation of groundwater discharge to

1131 the sea and thus recommend the following approaches (Table 6).

1132 Continuous ${ }^{222} \mathrm{Rn}$ measurements in coastal waters via boat surveys proved to be the most

1133 reliable method for detecting diffuse groundwater seepage through seabed sediments. The

1134 technique complements well with a ${ }^{222} \mathrm{Rn}$ mass balance model based on time-series

1135 measurements performed with the same instrumentation. We found that this method gives

1136 similar results to direct measurements carried out from Lee-type seepage meters.

1137 The presence of submarine springs was reliably detected using continuous salinity

1138 measurements and discreet ${ }^{224}$ Ra sampling. However, because negative salinity anomalies in

1139 coastal waters could be the result of discharge of other freshwater inputs (e.g. groundwater-fed

1140 creeks and coastal springs) which are likely to occur in karst systems, salinity alone is not a

1141 reliable tracer for SGD in coastal karst systems. We were able to confirm the presence of

1142 submerged springs only when combined with high concentrations of ${ }^{224} \mathrm{Ra}$ concentrations and

1143 direct observations via SCUBA diving. Direct flowmeter measurements or applying the ${ }^{222} \mathrm{Rn}$ 
1144 method would have been technically and economically challenging, given the springs depth and 1145 their lateral vent geometry.

1146 Subaerial coastal springs and groundwater-fed creeks are easily detectable visually in the

1147 field. However, we found that tracer surveys are helpful to identify sources of springs and 1148 assessing the total discharge from both forms of subaerial groundwater discharge.

1149 We found that the combination of hydrochemistry $\left(\mathrm{SO}_{4}^{-2}\right.$ and $\left.\mathrm{NO}_{3}{ }^{-}\right)$and water stable 1150 isotopes $\left(\delta^{2} \mathrm{H}\right.$ and $\left.\delta^{18} \mathrm{O}\right)$ was ideal to decipher the origin of each point of groundwater discharge 1151 to the sea.

1152 Nitrate fluxes, in an area where endemic and protected seagrasses Zostera marina, 1153 Posidonia oceanica are present, were found to be comparable with other coastal karst aquifers 1154 environmentally impacted by anthropogenic activities in the Mediterranean.

1155 Based on our experience, we strongly recommend the application of the described 1156 methodology approach in coastal karst systems to assess total groundwater discharge to the sea 1157 and associated nutrients fluxes.

1159 Acknowledgments

1160 This research was partially funded by the University of Alabama Graduate School Research and 1161 Travel Support Fund, the UA Department of Geological Sciences W. Gary Hooks Geological 1162 Sciences Advisory Board Fund, and the A.S. Johnson Travel Fund. This work is a contribution to 1163 the Research Group RNM-308 of the Junta de Andalucía, and CGL2015-65858-R of DGICYT. 1164 V.R. acknowledges support from the European Union’s Horizon 2020 research and innovation 1165 program under the Marie Skłodowska-Curie grant agreement No 748896. J.G.O would like to 1166 thank the support of the Generalitat de Catalunya to MERS (2014 SGR - 1356). We would also 
1167 want to thank José Antonio Espejel Carrión, Guillermo González Lozano, Javier López-Murcia

1168 Martin, Matías Mudarra Martínez, Diego Naranjo Roldán Fernando Nuño López, and Juan

1169 Manuel Ruiz for their extensive help in the field.

1170

1171 References

1172 Andreo, B., Carrasco, F., Sanz de Galdeano, C., 1993. Estudio geológico del entorno de la Cueva 1173 de Nerja. Geología de la Cueva de Nerja, 3, 25-50.

1174 Andreo, B., Carrasco, F., 1993. Estudio hidrogeológico del entorno de la Cueva de Nerja. 1175 Trabajos Cueva Nerja, 3, 163-187.

1176 Andreo, B., Vías, J., Durán, J. J., Jiménez, P., López-Geta, J. A., Carrasco, F., 2008.

1177 Methodology for groundwater recharge assessment in carbonate aquifers: application to pilot 1178 sites in southern Spain. Hydrogeology Journal, 16, 911-925.

1179 Andreo, B., Barberá, J. A., Mudarra, M., Marín, A. I., García-Orellana, J., Rodellas, V., Pérez, I., 1180 2017. A multi-method approach for groundwater resource assessment in coastal carbonate (karst) 1181 aquifers: the case study of Sierra Almijara (southern Spain). Hydrogeology Journal, 1-16.

1182 American Public Health Association (APHA), American Water Works Association (AWWA), 1183 and Water Environment Federation (WEF), 1999. In Clescerl L., Greenberg A., Eaton A. (Eds), 1184 Standard Methods for the Examination of Water and Wastewater 20th Edition. United Book 1185 Press, Inc., Baltimore, Maryland. Part 2000, pp. 2-48.

1186 Aranda, Y., Otero, M., 2014. Estudio de las figuras de protección de áreas marinas protegidas de 1187 Andalucía con fanerógamas marinas y propuestas de mejora para su gestión. Anexo VI. LIC 
1188 Arfib, B., Charlier, J. B., 2016. Insights into saline intrusion and freshwater resources in coastal 1189 karstic aquifers using a lumped Rainfall-Discharge-Salinity model (the Port-Miou brackish 1190 spring, SE France). Journal of Hydrology, 540, 148-161.

1191 Aunay, B., le Strat, P., Duvail, C., Dörfliger, N., Ladouche, B., 2003. Méthode d'analyse 1192 géologique sur la karstification des Corbières orientales et influence des évènements néogènes 1193 (tortono-messiniens). Hydrology of the Mediterranean and Semiarid Regions. IAHS, 1194 Montpellier, (278), 124-129

1195 Bakalowicz, M., 2005. Karst groundwater: a challenge for new resources. Hydrogeology Journal, 1196 13, 148-160.

1197 Bakalowicz, M., El Hakim, M., El-Hajj, A., 2008. Karst groundwater resources in the countries 1198 of eastern Mediterranean: the example of Lebanon. Environmental Geology, 54, 597-604.

1199 Bakalowicz, M., 2015. Karst and karst groundwater resources in the Mediterranean. 1200 Environmental Earth Sciences, 74, 5-14.

1201 Bañares-España E., Báez J.C., Casado M.D., Díaz de Rada C., Flores-Moya A., Rey J., 2002. 1202 Distribución y estado de las fanerógamas marinas en el Paraje natural Acantilados de Maro1203 Cerro gordo (Málaga-Granada). García-Gómez J.C., Finlayson C. (Eds.), Libro de Resúmenes, 1204 XII Simposio Ibérico del Bentos Marino, Impresur, Algeciras, 30-31.

1205 Barberá, J. A., Andreo, B., 2015. Hydrogeological processes in a fluviokarstic area inferred from 1206 the analysis of natural hydrogeochemical tracers. The case study of eastern Serranía de Ronda (S 1207 Spain). Journal of Hydrology, 523, 500-514. 
1208 Benac, Č., Rubinić, J., Ožanić, N., 2003. The origine and evolution of coastal and submarine 1209 springs in Bakar Bay. Acta Carsologica, 32, 157-171.

1210 Bonacci, O., Roje-Bonacci, T., 1997. Sea water intrusion in coastal karst springs: example of the 1211 Blaž Spring (Croatia). Hydrological Sciences Journal, 42, 89-100.

1212 Burnett, W. C., Taniguchi, M., Oberdorfer, J., 2001. Measurement and significance of the direct 1213 discharge of groundwater into the coastal zone. Journal of Sea Research, 46, 109-116.

1214 Burnett, W. C., Dulaiova, H., 2003. Estimating the dynamics of groundwater input into the 1215 coastal zone via continuous radon-222 measurements. Journal of Environmental Radioactivity, $1216 \quad 69,21-35$.

1217 Burnett, W. C., Bokuniewicz, H., Huettel, M., Moore, W. S., Taniguchi, M., 2003. Groundwater 1218 and pore water inputs to the coastal zone. Biogeochemistry, 66, 3-33.

1219 Burnett, W. C., Aggarwal, P. K., Aureli, A., Bokuniewicz, H., Cable, J. E., Charette, M. A., 1220 Kontar, E., Krupa, S., Kulkarni, K.M., Loveless, A., Moore, W. S., 2006. Quantifying 1221 submarine groundwater discharge in the coastal zone via multiple methods. Science of the Total 1222 Environment, 367, 498-543.

1223 Burnett, W. C., Santos, I. R., Weinstein, Y., Swarzenski, P. W., Herut, B., 2007. Remaining 1224 uncertainties in the use of Rn-222 as a quantitative tracer of submarine groundwater discharge. A 1225 New Focus on Groundwater-Seawater Interactions (Proceedings of Symposium HS1001 at 1226 IUGG2007, Perugia, July 2007. IAHS publication, 312, 109. 
1227 Burnett, W. C., Peterson, R., Moore, W. S., de Oliveira, J., 2008. Radon and radium isotopes as 1228 tracers of submarine groundwater discharge-results from the Ubatuba, Brazil SGD assessment 1229 intercomparison. Estuarine, Coastal and Shelf Science, 76, 501-511.

1230 Butscher, C., Huggenberger, P., 2007. Implications for karst hydrology from 3D geological 1231 modeling using the aquifer base gradient approach. Journal of hydrology, 342, 184-198.

1232 Cable, J. E., Burnett, W. C., Chanton, J. P., Weatherly, G. L., 1996. Estimating groundwater 1233 discharge into the northeastern Gulf of Mexico using radon-222. Earth and Planetary Science 1234 Letters, 144, 591-604.

1235 Carrasco, F., Durán, J. J., Andreo, B., Liñán, C., Vadillo, I., 1998. Consideraciones sobre el karst 1236 de Nerja. Karst en Andalucia, 173-181.

1237 Castillo, A., Carmona, J., Benavente Herrera, J., 2001. Cuantificación de los recursos hídricos en 1238 la vertiente meridional del Parque Natural de Sierra Almijara (Málaga). Consideraciones sobre 1239 su régimen de explotación. Geogaceta 29, 33-36.

1240 Cerdà-Domènech, M., Rodellas, V., Folch, A., García-Orellana, J., 2017. Constraining the 1241 temporal variations of $\mathrm{Ra}$ isotopes and $\mathrm{Rn}$ in the groundwater end-member: Implications for 1242 derived SGD estimates. Science of the Total Environment, 595, 849-857.

1243 Charette, M. A., Buesseler, K. O., Andrews, J. E., 2001. Utility of radium isotopes for evaluating 1244 the input and transport of groundwater-derived nitrogen to a Cape Cod estuary. Limnology and 1245 Oceanography, 46, 465-470. 
1246 Charette, M. A., 2007. Hydrologic forcing of submarine groundwater discharge: Insight from a 1247 seasonal study of radium isotopes in a groundwater-dominated salt marsh estuary. Limnology 1248 and Oceanography, 52, 230-239.

1249 Cockenpot, S., Claude, C., Radakovitch, O., 2015. Estimation of air-water gas exchange 1250 coefficient in a shallow lagoon based on ${ }^{222} \mathrm{Rn}$ mass balance. Journal of Environmental 1251 Radioactivity, 143, 58-69.

1252 Corbett, D., Burnett, W., Cable, P., Clark, S., 1998. A multiple approach to the determination of 1253 radon fluxes from sediments. Journal of Radioanalytical and Nuclear Chemistry, 236, 247-253.

1254 Craig, H., 1961. Isotopic variations in meteoric waters. Science, 133, 1702-1703

1255 Crusius, J., Koopmans, D., Bratton, J. F., Charette, M. A., Kroeger, K., Henderson, P., Ryckman, 1256 L., Halloran, K. Colman, J. A., 2005. Submarine groundwater discharge to a small estuary 1257 estimated from radon and salinity measurements and a box model. Biogeosciences, 2, 141-157.

1258 Custodio, E., 2010. Coastal aquifers of Europe: an overview. Hydrogeology Journal, 18, 2691259280.

1260 Deegan, L. A., Wright, A., Ayvazian, S. G., Finn, J. T., Golden, H., Merson, R. R., Harrison, J., 1261 2002. Nitrogen loading alters seagrass ecosystem structure and support of higher trophic levels. 1262 Aquatic Conservation: Marine and Freshwater Ecosystems, 12, 193-212.

1263 Dimova, N., Burnett, W. C., Lane-Smith, D., 2009. Improved automated analysis of radon $1264\left({ }^{222} \mathrm{Rn}\right)$ and thoron $\left({ }^{220} \mathrm{Rn}\right)$ in natural waters. Environmental Science \& Technology, 43, 859912658603. 
1266 Dimova, N. T., Burnett, W. C., Speer, K., 2011. A natural tracer investigation of the hydrological 1267 regime of Spring Creek Springs, the largest submarine spring system in Florida. Continental 1268 Shelf Research, 31, 731-738.

1269 Dimova, N. T., Swarzenski, P. W., Dulaiova, H., Glenn, C. R., 2012. Utilizing multichannel 1270 electrical resistivity methods to examine the dynamics of the fresh water-seawater interface in 1271 two Hawaiian groundwater systems. Journal of Geophysical Research: Oceans, 117, C02012, 1127212.

1273 Dimova, N. T., Paytan, A., Kessler, J. D., Sparrow, K. J., García-Tigreros Kodovska, F., Lecher, 1274 A. L., Murray, J. Tulaczyk, S. M., 2015. Current magnitude and mechanisms of groundwater 1275 discharge in the Arctic: case study from Alaska. Environmental Science \& Technology, 49, $1276 \quad 12036-12043$.

1277 Dulaiova, H., Peterson, R., Burnett, W.C., Lane-Smith, D., 2005. A multi-detector continuous 1278 monitor for assessment of ${ }^{222} \mathrm{Rn}$ in the coastal ocean. Journal of Radioanalytical and Nuclear 1279 Chemistry, 263 , 361-365.

1280 Dulaiova, H., Burnett, W. C., 2006. Radon loss across the water-air interface (Gulf of Thailand) 1281 estimated experimentally from ${ }^{222} \mathrm{Rn}-{ }^{224} \mathrm{Ra}$. Geophysical Research Letters, 33, L05606, 1-4.

1282 Durán, J. J., 1996. Los sistemas kársticos de la provincia de Málaga y su evolución. Contribución 1283 al conocimiento paleoclimático del Cuaternario en el Mediterráneo Occidental (Ph.D. 1284 Dissertation). Universidad Complutense de Madrid, Madrid, 409 p.

1285 Espejo, J.M., Luanco M. C., Linares L., 1988. Inventario de surgencias de aguas de origen 1286 continental en el litoral mediterráneo del sur de España, mediante utilización de sensores 
1287 térmicos aeroportados con apoyo de técnicas oceanográficas e hidrogeológicas. In: Fernández1288 Rubio, R., López-Geta, J. A., Ramos-González, G. (Eds.), Tecnología de la Intrusión en 1289 Acuiferos Costeros. TIAC’88, IGME, Madrid, pp. 191-228.

1290 Fleury, P., 2005. Sources sous-marines et aquifères karstiques côtiers méditerranéens. 1291 Fonctionnement et caractérisation. PhD dissertation, Université Paris VI, 286 p.

1292 Fleury, P., Bakalowicz, M., de Marsily, G., 2007. Submarine springs and coastal karst aquifers: a 1293 review. Journal of Hydrology, 339, 79-92.

1294 Fourniguet, J., 1975. Néotectonique et Quaternaire marin sur le littoral de la Sierra Nevada, 1295 Andalousie (Espagne). PhD dissertation. University of Orléans, 234 p.

1296 Gallego, M. A. B., Reyes, O. M., 2015. La población de meros Epinephelus marginatus en el 1297 litoral andaluz (España). Chronica Naturae, 5, 68-80.

1298 García-Solsona, E., García-Orellana, J., Masqué, P., Dulaiova, H., 2008. Uncertainties associated 1299 with $223 \mathrm{Ra}$ and $224 \mathrm{Ra}$ measurements in water via a Delayed Coincidence Counter (RaDeCC). 1300 Marine Chemistry, 109, 198-219.

1301 García-Solsona, E., García-Orellana, J., Masqué, P., Rodellas, V., Mejías, M., Ballesteros, B., 1302 Domínguez, J. A., 2010. Groundwater and nutrient discharge through karstic coastal springs 1303 (Castelló, Spain). Biogeosciences, 7, 2625-2638.

1304 García-Solsona, E., García-Orellana, J., Masqué, P., Garcés, E., Radakovitch, O., Mayer, A., 1305 Estradé, S Basterretxea, G., 2010. An assessment of karstic submarine groundwater and 1306 associated nutrient discharge to a Mediterranean coastal area (Balearic Islands, Spain) using 1307 radium isotopes. Biogeochemistry, 97, 211-229. 
1308 Gat, J.R., Garmi, I., 1970: Evolution of the isotopic composition of atmospheric waters in the 1309 Mediterranean Sea area. Journal of Geophysical Research., 75, 3039 - 3048.

1310 Gat, J. R., 1971. Comments on the stable isotope method in regional groundwater investigations.

1311 Water Resources Research, 7, 980-993.

1312 Gonneea, M. E., Charette, M. A., Liu, Q., Herrera-Silveira, J. A., Morales-Ojeda, S. M., 2014.

1313 Trace element geochemistry of groundwater in a karst subterranean estuary (Yucatan Peninsula, 1314 Mexico). Geochimica et Cosmochimica Acta, 132, 31-49.

1315 Guerra-Merchán, A., Serrano, F., 1993. Análisis estratigráfico de los materiales neógeno1316 cuaternarios de la región de Nerja. Geología de la Cueva de Nerja, 3, 53-90.

1317 Hallegraeff, G. M., 1993. A review of harmful algal blooms and their apparent global increase. 1318 Phycologia, 32, 79-99.

1319 Hauxwell, J., Cebrián, J., Furlong, C., Valiela, I., 2001. Macroalgal canopies contribute to 1320 eelgrass (Zostera marina) decline in temperate estuarine ecosystems. Ecology, 82, 1007-1022.

1321 Hughes, A. R., Williams, S. L., Duarte, C. M., Heck, K. L., Waycott, M., 2009. Associations of 1322 concern: declining seagrasses and threatened dependent species. Frontiers in Ecology and the 1323 Environment, 7, 242-246.

1324 Isiorho, S. A., Meyer, J. H., 1999. The effects of bag type and meter size on seepage meter 1325 measurements. Ground Water, 37, 411-413.

1326 Johnson, A. G., Glenn, C. R., Burnett, W. C., Peterson, R. N., Lucey, P. G., 2008. Aerial infrared 1327 imaging reveals large nutrient-rich groundwater inputs to the ocean. Geophysical Research 1328 Letters, 35, L15606, 1-6. 
1329 Johnson, A. G. (2008). Groundwater discharge from the leeward half of the Big Island, Hawai' $i$.

1330 PhD dissertation. University of Hawai'I, 145 p.

1331 Jordá, J.F., 1988. Los travertinos del extremo oriental de la costa de Málaga. Actas del II 1332 Congreso Geológico de España, Universidad de Granada y Sociedad Geológica de España. 1333 Granada, 391-394.

1334 Jordá, J. F., Aura Tortosa, J. E., Álvarez Fernández, E., Avezuela Aristu, B., Badal, E., Maestro 1335 González, A., Villalba Currás, M. P., 2011. Evolución paleogeográfica, paleoclimática y 1336 paleoambiental de la costa meridional de la Península Ibérica durante el Pleistoceno superior. El 1337 caso de la Cueva de Nerja (Málaga, Andalucía, España). Boletín de la Real Sociedad Española 1338 de Historia Natural, 105, 137-147.

1339 Katz, B. G., Griffin, D. W., Davis, J. H., 2009. Groundwater quality impacts from the land 1340 application of treated municipal wastewater in a large karstic spring basin: chemical and 1341 microbiological indicators. Science of the Total Environment, 407, 2872-2886.

1342 Knee, K. L., Street, J. H., Grossman, E. E., Boehm, A. B., Paytan, A., 2010. Nutrient inputs to 1343 the coastal ocean from submarine groundwater discharge in a groundwater-dominated system: 1344 relation to land use (Kona coast, Hawai'i, USA). Limnology and Oceanography, 55, 1105-1122.

1345 Kremer, J. N., Reischauer, A., D’Avanzo, C., 2003. Estuary-specific variation in the air-water 1346 gas exchange coefficient for oxygen. Estuaries and Coasts, 26, 829-836.

1347 Lee, D. R., 1977. A device for measuring seepage flux in lakes and estuaries. Limnology and 1348 Oceanography, 22, 140-147. 
1349 Liñán, C., Andreo, B., Carrasco, F., 2000. Caracterización hidrodinámica e hidroquímica del 1350 manantial de Maro (Sierra Almijara, provincia de Málaga). Geogaceta, 27, 95-98.

1351 Macintyre, S., Wannikhof, R., Chanton, J.P., 1995. Trace gas exchange across the air-water 1352 interface in freshwater and coastal marine environments. In: Matson, P.A., Harriss, R.C. (Eds.), 1353 Biogenic Trace Gases: Measuring Emissions from Soil and Water. pp. 52-57.

1354 Martens, C. S., Klump, J. V., Kipphut, G. W., 1980. Sediment-water chemical exchange in the 1355 coastal zone traced by in situ radon-222 flux measurements. Science, 208, 285-288.

1356 Martínez-Santos, P., Andreu, J. M., 2010. Lumped and distributed approaches to model natural 1357 recharge in semiarid karst aquifers. Journal of Hydrology, 388, 389-398.

1358 McCormack, T., Gill, L. W., Naughton, O., Johnston, P. M., 2014. Quantification of 1359 submarine/intertidal groundwater discharge and nutrient loading from a lowland karst catchment. 1360 Journal of Hydrology, 519, 2318-2330.

1361 Mejías, M., García-Orellana, J., Plata, J. L., Marina, M., García-Solsona, E., Ballesteros, B., 1362 Masqué, P., López, J., Fernández-Arrojo, C., 2008. Methodology of hydrogeological 1363 characterization of deep carbonate aquifers as potential reservoirs of groundwater. Case of study: 1364 the Jurassic aquifer of El Maestrazgo (Castellón, Spain). Environmental Geology, 54, 521-536.

1365 Mejías, M., Ballesteros, B. J., Antón-Pacheco, C., Domínguez, J. A., García-Orellana, J., García1366 Solsona, E., Masqué, P., 2012. Methodological study of submarine groundwater discharge from 1367 a karstic aquifer in the Western Mediterranean Sea. Journal of Hydrology, 464, 27-40.

1368 Moore, W. S., 1976. Sampling ${ }^{228}$ Ra in the deep ocean. Deep Sea Research and Oceanographic 1369 Abstracts, 23, 647-651. 
1370 Moore, W. S., 1996. Large groundwater inputs to coastal waters revealed by ${ }^{226}$ Ra enrichments. $1371 \quad$ Nature, 380, 612-614.

1372 Moore, W. S., Arnold, R., 1996. Measurement of ${ }^{223} \mathrm{Ra}$ and ${ }^{224} \mathrm{Ra}$ in coastal waters using a 1373 delayed coincidence counter. Journal of Geophysical Research, 101, 1321-1329.

1374 Moore, W. S., 2000. Determining coastal mixing rates using radium isotopes. Continental Shelf 1375 Research, 20, 1993-2007.

1376 Moore, W. S., 2006. Radium isotopes as tracers of submarine groundwater discharge in Sicily. 1377 Continental Shelf Research, 26, 852-861.

1378 Moore, W. S., 2008. Fifteen years experience in measuring ${ }^{224} \mathrm{Ra}$ and ${ }^{223}$ Ra by delayed1379 coincidence counting. Marine Chemistry, 109, 188-197.

1380 Moore, W. S., 2010. The effect of submarine groundwater discharge on the ocean. Annual 1381 Review of Marine Science, 2, 59-88.

1382 Null, K. A., Knee, K. L., Crook, E. D., de Sieyes, N. R., Rebolledo-Vieyra, M., Hernández1383 Terrones, L., Paytan, A., 2014. Composition and fluxes of submarine groundwater along the 1384 Caribbean coast of the Yucatan Peninsula. Continental Shelf Research, 77, 38-50.

1385 Pérez-Ramos, I. Andreo, B., 2007. Masas de aguas subterráneas de Alberquillas y Sierra 1386 Almijara. Atlas hidrogeológico de la Provincia Málaga. Coordinador general Duran, J. J. 1387 Instituto Geológico y Minero de España, Diputación de Malaga. Tomo 2, 143-148.

1388 Peterson, R. N., Burnett, W. C., Glenn, C. R., Johnson, A. G., 2009. Quantification of point1389 source groundwater discharges to the ocean from the shoreline of the Big Island, 1390 Hawaii. Limnol. Oceanogr, 54, 890-904. 
1391 Pinault, J. L., Dörfliger, N., Ladouche, B., Bakalowicz, M., 2004. Characterizing a coastal karst 1392 aquifer using an inverse modeling approach: The saline springs of Thau, southern France. Water 1393 Resources Research, 40, W08501, 1-17.

1394 Pluhowski, E. J., 1972. Hydrologic interpretations based on infrared imagery of Long Island, 1395 New York. USGS Water-Supply paper 2009-B.

1396 Rapaglia, J., Grant, C., Bokuniewicz, H., Pick, T., Scholten, J., 2015. A GIS typology to locate 1397 sites of submarine groundwater discharge. Journal of Environmental Radioactivity, 145, 10-18.

1398 Rapport, D. J., Whitford, W. G., 1999. How Ecosystems Respond to Stress Common properties 1399 of arid and aquatic systems. BioScience, 49, 193-203.

1400 Rodellas, V., García-Orellana, J., García-Solsona, E., Masqué, P., Domínguez, J. A., Ballesteros, 1401 B. J., Mejías, M., Zarroca, M., 2012. Quantifying groundwater discharge from different sources 1402 into a Mediterranean wetland by using ${ }^{222} \mathrm{Rn}$ and Ra isotopes. Journal of Hydrology, 466, 11-22.

1403 Rodellas, V., García-Orellana, J., Tovar-Sánchez, A., Basterretxea, G., López-García, J. M., 1404 Sánchez-Quiles, D., García-Solsona, E., Masqué, P., 2014. Submarine groundwater discharge as 1405 a source of nutrients and trace metals in a Mediterranean bay (Palma Beach, Balearic Islands). 1406 Marine Chemistry, 160, 56-66.

1407 Rodellas, V., García-Orellana, J., Masqué, P., Feldman, M., Weinstein, Y., 2015. Submarine 1408 groundwater discharge as a major source of nutrients to the Mediterranean Sea. Proceedings of 1409 the National Academy of Sciences, 112, 3926-3930.

1410 Rosenberry, D. O., 2008. A seepage meter designed for use in flowing water. Journal of 1411 Hydrology, 359, 118-130. 
1412 Sadat-Noori, M., Santos, I. R., Sanders, C. J., Sanders, L. M., Maher, D. T., 2015. Groundwater 1413 discharge into an estuary using spatially distributed radon time series and radium 1414 isotopes. Journal of Hydrology, 528, 703-719.

1415 Santos, I. R., Burnett, W. C., Chanton, J., Dimova, N., Peterson, R. N. (2009). Land or ocean?: 1416 Assessing the driving forces of submarine groundwater discharge at a coastal site in the Gulf of 1417 Mexico. Journal of Geophysical Research: Oceans, 114, C04012, 1-11.

1418 Schincariol, R. A., McNeil, J. D., 2002. Errors with small volume elastic seepage meter bags. 1419 Ground water, 40, 649-651.

1420 Smith, C. G., Swarzenski, P. W., 2012. An investigation of submarine groundwater-borne 1421 nutrient fluxes to the west Florida shelf and recurrent harmful algal blooms. Limnology and 1422 oceanography, 57, 471-485.

1423 Stamatis, G., Migiros, G., Kontari, A., Dikarou, E., Gamvroula, D., 2011. Application of tracer 1424 method and hydrochemical analyses regarding the investigation of the coastal karstic springs and 1425 the submarine spring (Anavalos) in Stoupa Bay (W. Mani Peninsula). Advances in the Research 1426 of Aquatic Environment Springer Berlin Heidelberg, 459-467.

1427 Stieglitz, T. C., Cook, P. G., Burnett, W. C., 2010. Inferring coastal processes from regional1428 scale mapping of 222 Radon and salinity: examples from the Great Barrier Reef, Australia. 1429 Journal of environmental radioactivity, 101, 544-552.

1430 Stringfield, V. T., LeGrand, H. E., 1971. Effects of karst features on circulation of water in 1431 carbonate rocks in coastal areas. Journal of Hydrology, 14, 139-157. 
1432 Sun, Y., Torgersen, T., 1998. The effects of water content and Mn-fiber surface conditions on 1433 224Ra measurement by 220Rn emanation. Marine Chemistry, 62, 299-306.

1434 Surić, M., Lončarić, R., Buzjak, N., Schultz, S. T., Šangulin, J., Maldini, K., Tomas, D., 2015. 1435 Influence of submarine groundwater discharge on seawater properties in Rovanjska-Modrič karst 1436 region (Croatia). Environmental Earth Sciences, 74, 5625-5638.

1437 Tamborski, J. J., Rogers, A. D., Bokuniewicz, H. J., Cochran, J. K., Young, C. R., 2015. 1438 Identification and quantification of diffuse fresh submarine groundwater discharge via airborne 1439 thermal infrared remote sensing. Remote Sensing of Environment, 171, 202-217.

1440 Taniguchi, M., Burnett, W. C., Cable, J. E., Turner, J. V., 2002. Investigation of submarine 1441 groundwater discharge. Hydrological Processes, 16, 2115-2129.

1442 Taniguchi, M., Ishitobi, T., Saeki, K. I., 2005. Evaluation of time-space distributions of 1443 submarine ground water discharge. Ground Water, 43, 336-342.

1444 Taniguchi, M., Ishitobi, T., Chen, J., Onodera, S. I., Miyaoka, K., Burnett, W. C., Peterson, R., 1445 Liu, G., Fukushima, Y., 2008. Submarine groundwater discharge from the Yellow River delta to 1446 the Bohai Sea, China. Journal of Geophysical Research: Oceans, 113, C06025, 1-11.

1447 Theodorou, J. A., James, R., Tzovenis, I., Hellio, C., 2015. The recruitment of the endangered 1448 fan mussel Pinna nobilis (Linnaeus, 1758) on the ropes of a Mediterranean mussel long line 1449 farm. Journal of Shellfish Research, 34, 409-414.

1450 Tomas, J., Aznar, F. J., Raga, J. A., 2001. Feeding ecology of the loggerhead turtle Caretta 1451 caretta in the western Mediterranean. Journal of Zoology, 255, 525-532. 
1452 Tovar-Sánchez, A., Basterretxea, G., Rodellas, V., Sánchez-Quiles, D., García-Orellana, J., 1453 Masqué, P., García-Solsona, E., 2014. Contribution of groundwater discharge to the coastal 1454 dissolved nutrients and trace metal concentrations in Majorca Island: karstic vs detrital systems. 1455 Environmental Science Technology, 48, 11819-11827.

1456 Trezzi, G., García-Orellana, J., Rodellas, V., Santos-Echeandia, J., Tovar-Sánchez, A., García1457 Solsona, E., Masqué, P., 2016. Submarine groundwater discharge: A significant source of 1458 dissolved trace metals to the North Western Mediterranean Sea. Marine Chemistry, 186, 90-100.

1459 Trezzi, G., García-Orellana, J., Rodellas, V., Masqué, P., García-Solsona, E., Andersson, P. S., 1460 2017. Assessing the role of submarine groundwater discharge as a source of $\mathrm{Sr}$ to the 1461 Mediterranean Sea. Geochimica et Cosmochimica Acta, 200, 42-54.

1462 Valiela, I., Foreman, K., LaMontagne, M., Hersh, D., Costa, J., Peckol, P., DeMeo-Andreson, B., 1463 D’Avanzo, C., Babione, M., Sham, C.H., Brawley, J., 1992. Couplings of watersheds and coastal 1464 waters: sources and consequences of nutrient enrichment in Waquoit Bay, Massachusetts. 1465 Estuaries, 15, 443-457.

1466 Valiela, I., Cole, M. L., 2002. Comparative evidence that salt marshes and mangroves may 1467 protect seagrass meadows from land-derived nitrogen loads. Ecosystems, 5, 92-102.

1468 Webster, I. T., Hancock, G. J., Murray, A. S., 1995. Modelling the effect of salinity on radium 1469 desorption from sediments. Geochimica et Cosmochimica Acta, 59, 2469-2476.

1470 Weinstein, Y., Yechieli, Y., Shalem, Y., Burnett, W. C., Swarzenski, P. W., Herut, B., 2011. 1471 What is the role of fresh groundwater and recirculated seawater in conveying nutrients to the 1472 coastal ocean? Environmental Science Technology, 45, 5195-5200. 
1473 Wong, W. W., Grace, M. R., Cartwright, I., Cardenas, M. B., Zamora, P. B., Cook, P. L., 2013. 1474 Dynamics of groundwater-derived nitrate and nitrous oxide in a tidal estuary from radon mass 1475 balance modeling. Limnol. Oceanogr, 58, 1689-1706.

1476 Worthington, S. R. H., 1999. A comprehensive strategy for understanding flow in carbonate 1477 aquifers. In Palmer A. N., Palmer M. V., Sasowsky I. D. (Eds), Karst Modeling. Karst Waters 1478 Institute, pp. 30-37.

1479 Yobbi, D. K., 1992. Effects of tidal stage and ground-water levels on the discharge and water 1480 quality of springs in coastal Citrus and Hernando Counties, Florida, US Department of the 1481 Interior. US Geological Survey, 44 p.

1482

1483

1484

1485

1486

1487

1488

1489

1490

1491

1492

1493

1494

1495

1496 


\section{List of Tables}

1499 Table 1: Summary of values for all terms used to solve the radium and salinity mass balances to asses 1500 submarine springs discharge in the karst section. Calculated total flux $\left(F_{S G D}\right)$ using both methods are also 1501 shown.

Table 2: Parameters used in the radon mass balance to asses diffuse seepage in Maro Cliff (conglomerate 1504 section) and Cantarrijan Beach (karst section) including estimated groundwater fluxes $\left(F_{S G D}\right)$.

1506 Table 3: Comparison of groundwater seepage velocities estimated via radon model and seepage meters 1507 during July of 2016 (dry period) in Maro Cliff (conglomerate section) and Cantarrijan Beach (karst 1508 section).

Table 4: Summary of total groundwater discharge (TGD) including all modes of discharge (CS, GC, GS, 1511 SS), and fresh groundwater discharge from the Sierra Almijara-Alberquillas (SAA) aquifer (daily and 1512 annual). Total nitrate fluxes to coastal waters (N-TGD) in the three sections (conglomerate, Schist, and 1513 Karst sections), with respect to agricultural coverage. Relative agricultural area represents the coverage 1514 normalized by the total extension of each section near the coast.

Table 5: Values of all parameters applied in the sensitivity analysis including flux ranges estimated for 1517 each methodology.

1519 Table 6: Applicability comparison of all methods utilized to detect and quantify different modes of 1520 groundwater discharge to the sea. Flux ranges are based on maxima and minima estimations obtained in 
1521 the sensitivity analysis. Daily fluxes are shown for each form of discharge and method, and annual water 1522 budget (fresh) of Sierra Almijara-Alberquillas (SAA). 


\begin{tabular}{|c|c|c|c|c|c|c|c|c|c|}
\hline & \multicolumn{3}{|c|}{ Radium (1) mass balance } & \multicolumn{6}{|c|}{ Salinity mass balance (2) } \\
\hline & $\mathrm{Ra}_{\mathrm{sw}}$ & 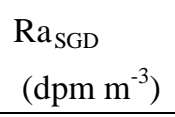 & $\mathrm{Ra}_{\mathrm{ow}}$ & $\mathrm{Sal}_{\mathrm{sw}}$ & $\mathrm{Sal}_{\mathrm{SGD}}$ & $\mathrm{Sal}_{\mathrm{ow}}$ & $\begin{array}{c}\mathrm{V} \\
\left(\times 10^{5} \mathrm{~m}^{3}\right)\end{array}$ & $\begin{array}{r}F_{S G D}(1) \\
(\times 1)\end{array}$ & $\begin{array}{l}F_{S G D}(2) \\
\left.d^{-1}\right)\end{array}$ \\
\hline Cantarrijan & $25 \pm 2$ & $1260 \pm 90$ & $8 \pm 1$ & $36.3 \pm 0.1$ & 0.0 & 36.5 & 2.67 & $4.7 \pm 0.5$ & $0.8 \pm 0.1$ \\
\hline Palomas & $18 \pm 2$ & $1260 \pm 90$ & $8 \pm 1$ & $36.4 \pm 0.1$ & 0.0 & 36.5 & 4.04 & $4.3 \pm 0.5$ & $0.9 \pm 0.1$ \\
\hline Sifon & $17 \pm 2$ & $1260 \pm 90$ & $8 \pm 1$ & $36.4 \pm 0.1$ & 0.0 & 36.5 & 3.72 & $3.7 \pm 0.4$ & $0.5 \pm 0.1$ \\
\hline Total flux & & & & & & & & $12.8 \pm 1.4$ & $2.3 \pm 0.2$ \\
\hline
\end{tabular}

Table 1 


\begin{tabular}{|c|c|c|c|c|c|c|c|c|c|c|}
\hline & & $\begin{array}{c}\mathrm{Rn}_{\mathrm{SGD}} \\
\left(\times 10^{3} \mathrm{dpm} \mathrm{m}^{-3}\right)\end{array}$ & 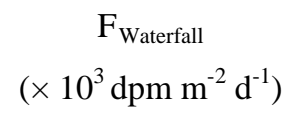 & 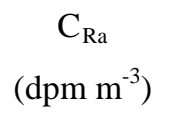 & $\begin{array}{c}F_{\text {Diff }} \\
\left(\mathrm{dpm} \mathrm{m}^{-2} \mathrm{~d}^{-1}\right)\end{array}$ & $\begin{array}{l}\mathrm{F}_{\text {Mix }} \\
\left(\times 10^{3} \mathrm{~d}_{\mathrm{f}}\right.\end{array}$ & $\begin{array}{l}\mathrm{F}_{\mathrm{Atm}} \\
\left.\mathrm{d}^{-1}\right)\end{array}$ & $\begin{array}{l}\text { Seepage Area } \\
\qquad\left(\times 10^{3} \mathrm{~m}^{2}\right)\end{array}$ & $\begin{array}{l}\text { SGD } \\
\left(\mathrm{cm} \mathrm{d}^{-1}\right)\end{array}$ & $\begin{array}{c}\mathrm{F}_{\mathrm{SGD}} \\
\left(\times 10^{3} \mathrm{~m}^{3} \mathrm{~d}^{-1}\right)\end{array}$ \\
\hline \multirow{3}{*}{ Maro Cliff } & Jul-15 & $350 \pm 50$ & $16 \pm 6$ & $280 \pm 50$ & $619 \pm 57$ & $149 \pm 40$ & $33 \pm 9$ & 7.7 & $39 \pm 10$ & $3.0 \pm 0.8$ \\
\hline & Dec-15 & $440 \pm 60$ & $21 \pm 8$ & $280 \pm 50$ & $619 \pm 57$ & $238 \pm 64$ & $11 \pm 3$ & 7.7 & $40 \pm 11$ & $3.1 \pm 0.8$ \\
\hline & Jul-16 & $320 \pm 30$ & $10 \pm 5$ & $280 \pm 50$ & $619 \pm 57$ & $160 \pm 43$ & $25 \pm 7$ & 7.7 & $38 \pm 10$ & $2.9 \pm 0.7$ \\
\hline \multirow{3}{*}{$\begin{array}{l}\text { Cantarrijan } \\
\text { Beach }\end{array}$} & Jul-15 & $310 \pm 70$ & N/A & $170 \pm 40$ & $455 \pm 51$ & - & & 4.3 & - & - \\
\hline & Dec-15 & $240 \pm 60$ & N/A & $170 \pm 40$ & $455 \pm 51$ & $84 \pm 13$ & $30 \pm 5$ & 4.3 & $52 \pm 8$ & $2.3 \pm 0.3$ \\
\hline & Jul-16 & $350 \pm 40$ & N/A & $170 \pm 40$ & $455 \pm 51$ & $115 \pm 18$ & $27 \pm 4$ & 4.3 & $22 \pm 3$ & $0.9 \pm 0.1$ \\
\hline
\end{tabular}

Table 2 


\begin{tabular}{lcc}
\hline & \multicolumn{2}{c}{ SGD seepage rate $\left(\mathrm{cm} \mathrm{d}^{-1}\right)$} \\
& Maro Cliff & Cantarrijan Beach \\
\hline Radon model & $38 \pm 10$ & $22 \pm 3$ \\
Seepage meters & $28 \pm 7$ & $23 \pm 7$ \\
SM-1 & 19 & 13 \\
SM-2 & 32 & 32 \\
SM-3 & 37 & 26 \\
SM-4 & 25 & 20 \\
SM-5 & & 0 \\
SM-6 & & 1 \\
SM-7 & & 0 \\
SM-8 & & 0 \\
SM-9 & & 1 \\
\hline
\end{tabular}

Table 3 


\begin{tabular}{|c|c|c|c|c|c|c|c|c|c|c|}
\hline & $\begin{array}{c}\text { TGD } \\
\left(\times 10^{3} \mathrm{~m}^{3} \mathrm{~d}^{-1}\right)\end{array}$ & CS & $\begin{array}{l}\text { GC } \\
(\times 10\end{array}$ & $\left.d^{-1}\right)$ & SS & $\begin{array}{l}\text { Fresh TGD } \\
\text { from SAA } \\
\left(\times 10^{3} \mathrm{~m}^{3} \mathrm{~d}^{-1}\right)\end{array}$ & $\begin{array}{c}\text { Annual } \\
\text { budget SAA } \\
\left(\times 10^{6} \mathrm{~m}^{3} \mathrm{y}^{-1}\right)\end{array}$ & $\begin{array}{c}\text { Agricultural } \\
\text { area } \\
\left(\mathrm{km}^{2}\right)\end{array}$ & $\begin{array}{c}\text { Relative } \\
\text { agricultural } \\
\text { area } \\
(\%)\end{array}$ & $\begin{array}{l}\text { N-TGD } \\
\left(\mathrm{mol} \mathrm{d}^{-1}\right)\end{array}$ \\
\hline $\begin{array}{l}\text { Conglomerate } \\
\text { section }\end{array}$ & $3.5-4.0$ & $0.5-0.8$ & $0.1-0.2$ & $2.9-3.0$ & 0 & $0.1-0.2$ & $0.06-0.08$ & 204 & 95 & $550-732$ \\
\hline $\begin{array}{l}\text { Schist } \\
\text { section }\end{array}$ & $2.4-3.6$ & $1.1-1.6$ & $1.3-2.0$ & 0 & 0 & $2.3-3.4$ & $0.8-1.2$ & 103 & 7 & $136-204$ \\
\hline $\begin{array}{l}\text { Karst } \\
\text { section }\end{array}$ & $3.0-4.8$ & 0 & 0 & $0.9-2.3$ & $2.1-2.5$ & $2.5-3.6$ & $1.0-1.3$ & 0 & 0 & $18-53$ \\
\hline
\end{tabular}

Table 4 


\begin{tabular}{|c|c|c|c|c|c|c|c|c|c|c|c|c|}
\hline \multirow{3}{*}{$\begin{array}{l}\text { Method/Form of } \\
\text { discharge }\end{array}$} & \multirow{3}{*}{$\begin{array}{l}\text { Residence } \\
\text { time } \\
\text { (days) }\end{array}$} & \multirow{3}{*}{$\begin{array}{l}{ }^{224} \mathrm{Ra} \text { gw } \\
\text { end- } \\
\text { member } \\
\left(\mathrm{dpm} \mathrm{m} \mathrm{m}^{-3}\right)\end{array}$} & \multirow{3}{*}{$\begin{array}{l}\text { Salinity } \\
\text { isoline }\end{array}$} & \multicolumn{5}{|c|}{ Model parameters } & & & \multirow{3}{*}{$\begin{array}{l}\text { Final SGD } \\
\text { estimate } \\
\left(\times 10 \mathrm{~m}^{3} \mathrm{~d}^{-1}\right)\end{array}$} & \multirow{3}{*}{$\begin{array}{c}\text { Percentage } \\
\text { difference } \\
\text { between min } \\
\text { and max } \\
\text { estimate }\end{array}$} \\
\hline & & & & \multicolumn{3}{|c|}{$\begin{array}{l}\text { Volume SGD plume } \\
\qquad\left(\mathrm{x} 10^{5} \mathrm{~m}^{3}\right)\end{array}$} & \multicolumn{2}{|c|}{$\begin{array}{l}{ }^{222} \mathrm{Rn} \text { isoline } \\
\left(\mathrm{x} 10^{3} \mathrm{dpm} \mathrm{m}^{-3}\right)\end{array}$} & \multicolumn{2}{|c|}{$\begin{array}{l}\text { Seepage area } \\
\left(\mathrm{x} 10^{3} \mathrm{~m}^{2}\right)\end{array}$} & & \\
\hline & & & & Cantarrijan & Palomas & Sifon & Maro Cliff & $\begin{array}{l}\text { Cantarrijan } \\
\text { Beach }\end{array}$ & Maro Cliff & $\begin{array}{l}\text { Cantarrijan } \\
\text { Beach }\end{array}$ & & \\
\hline \multirow{5}{*}{$\begin{array}{l}\text { Salinity mass } \\
\text { balance/Submarine } \\
\text { springs }\end{array}$} & 0.25 & N/A & $\begin{array}{l}-0.3 \\
\end{array}$ & 0.9 & 1.5 & 1.1 & N/A & N/A & N/A & N/A & \multirow{5}{*}{$0.2-90.5$} & \multirow{5}{*}{$100 \%$} \\
\hline & 0.50 & N/A & 0.0 & 2.6 & 4.0 & 3.7 & N/A & N/A & N/A & N/A & & \\
\hline & 1.00 & N/A & 0.3 & 2.8 & 5.4 & 4.7 & N/A & N/A & N/A & N/A & & \\
\hline & 3.00 & N/A & 0.6 & 4.6 & 8.7 & 7.1 & N/A & N/A & N/A & N/A & & \\
\hline & $0.5 \mathrm{~m}$ wa & r column & 0.0 & 0.20 & 0.18 & 0.19 & N/A & N/A & N/A & N/A & & \\
\hline \multirow{5}{*}{$\begin{array}{l}{ }^{224} \text { Ra mass } \\
\text { balance/Submarine } \\
\text { springs }\end{array}$} & 0.25 & \multirow{2}{*}{$1020 \pm 80$} & -0.3 & 0.9 & 1.5 & 1.1 & N/A & N/A & N/A & N/A & \multirow{5}{*}{$0.03-13.5$} & \multirow{5}{*}{$100 \%$} \\
\hline & 0.50 & & 0.0 & 2.6 & 4.0 & 3.7 & N/A & N/A & N/A & N/A & & \\
\hline & 1.00 & & 0.3 & 2.8 & 5.4 & 4.7 & N/A & N/A & N/A & N/A & & \\
\hline & 3.00 & $1260 \pm 90$ & 0.6 & 4.6 & 8.7 & 7.1 & N/A & N/A & N/A & N/A & & \\
\hline & $0.5 \mathrm{~m}$ wa & r column & 0.0 & 0.20 & 0.18 & 0.19 & N/A & N/A & N/A & N/A & & \\
\hline \multirow{4}{*}{$\begin{array}{l}{ }^{222} \mathrm{Rn} \text { mass } \\
\text { balance/Diffuse } \\
\text { seepage }\end{array}$} & N/A & N/A & N/A & N/A & N/A & N/A & 25 & 5 & 2.4 & 1.0 & \multirow{4}{*}{$1.1-10.0$} & \multirow{4}{*}{$89 \%$} \\
\hline & N/A & N/A & N/A & N/A & N/A & N/A & 30 & 6 & 7.7 & 3.2 & & \\
\hline & N/A & N/A & N/A & N/A & N/A & N/A & 35 & 8 & 10.6 & 4.3 & & \\
\hline & N/A & N/A & N/A & N/A & N/A & N/A & 45 & 10 & 17.8 & 5.7 & & \\
\hline \multirow{4}{*}{$\begin{array}{l}\text { Seepage } \\
\text { meters/Diffuse } \\
\text { seepage }\end{array}$} & N/A & N/A & N/A & N/A & N/A & N/A & 25 & 5 & 2.4 & 1.0 & \multirow{4}{*}{$1.2-9.1$} & \multirow{4}{*}{$87 \%$} \\
\hline & N/A & N/A & N/A & N/A & N/A & N/A & 30 & 6 & 7.7 & 3.2 & & \\
\hline & N/A & N/A & N/A & N/A & N/A & N/A & 35 & 8 & 10.6 & 4.3 & & \\
\hline & N/A & N/A & N/A & N/A & N/A & N/A & 45 & 10 & 17.8 & 5.7 & & \\
\hline
\end{tabular}

Table 5 


\begin{tabular}{|c|c|c|c|c|c|c|c|c|c|}
\hline \multirow{2}{*}{$\begin{array}{l}\text { Mode of } \\
\text { groundwater (GW) } \\
\text { discharge / site name }\end{array}$} & \multicolumn{2}{|c|}{${ }^{224}$ Ra method } & \multicolumn{2}{|c|}{${ }^{222}$ Rn method } & \multicolumn{2}{|c|}{ Salinity method } & \multicolumn{2}{|c|}{ Seepage meter method } & \multirow{2}{*}{$\begin{array}{l}\text { Flow meter method } \\
\text { Flux } \\
\left.\qquad \times 10^{3} \mathrm{~m}^{3} \mathrm{~d}^{-1}\right)\end{array}$} \\
\hline & $\begin{array}{l}\text { Obs. anomaly } \\
\text { in seawater }\end{array}$ & $\begin{array}{c}\text { Flux } \\
\left(\times 10^{3} \mathrm{~m}^{3} \mathrm{~d}^{-1}\right)\end{array}$ & $\begin{array}{c}\text { Obs. anomaly } \\
\text { in seawater }\end{array}$ & $\underset{\left(\times 10^{3} \mathrm{~m}^{3} \mathrm{~d}^{-1}\right)}{\text { Flux }}$ & $\begin{array}{c}\text { Obs. anomaly } \\
\text { in seawater }\end{array}$ & $\begin{array}{c}\text { Flux } \\
\left(\times 10^{3} \mathrm{~m}^{3} \mathrm{~d}^{-1}\right)\end{array}$ & $\begin{array}{c}\text { Obs. anomaly } \\
\text { in seawater }\end{array}$ & $\underset{\left(\times 10^{3} \mathrm{~m}^{3} \mathrm{~d}^{-1}\right)}{\text { Flux }}$ & \\
\hline $\begin{array}{l}\text { GW-fed creeks } \\
\text { Caleta } \\
\text { Tierras Nuevas } \\
\text { Miel }\end{array}$ & $\checkmark$ & N/A & $x$ & N/A & $\checkmark$ & N/A & $x$ & N/A & $1.4-2.2$ \\
\hline $\begin{array}{l}\text { Coastal springs } \\
\text { Doncellas } \\
\text { Barranco Maro } \\
\text { Huerto Romero } \\
\text { Maro Beach } \\
\text { Alberquillas }\end{array}$ & $x$ & N/A & $x$ & N/A & $\checkmark$ & N/A & $x$ & N/A & $1.6-2.4$ \\
\hline $\begin{array}{l}\text { Submarine springs } \\
\text { Cantarrijan } \\
\text { Palomas } \\
\text { Sifon }\end{array}$ & $\checkmark$ & $0.2-90.5$ & $x$ & N/A & $\checkmark$ & $0.03-13.5$ & $x$ & N/A & N/A \\
\hline $\begin{array}{l}\text { Diffused seepage } \\
\text { Maro Cliff } \\
\text { Cantarrijan Beach }\end{array}$ & $x$ & N/A & $\checkmark$ & $1.1-10.0$ & $\checkmark$ & N/A & $\checkmark$ & $1.2-9.1$ & N/A \\
\hline
\end{tabular}

Table 6 


\section{List of figures}

2

3 Figure 1: Study site location and geological map showing water table contour lines (from Pérez-

4 Ramos and Andreo, 2007), groundwater flow direction, important wells and piezometers, 5 sampling points, and terrestrial springs. Groundwater discharge to the sea (TGD) is represented

6 in purple and is based on this study. Coastal springs are represented as CS, groundwater-fed

7 creeks as GC, diffuse groundwater seepage as GS, and submarine springs as SS. The study area

8 is divided in three sections: conglomerate section, schist section, and karst section. The

9 distribution of seagrass beds are based on Bañares-España et al. (2002), and Aranda and Otero 10 (2014).

12 Figure 2: Average monthly precipitation and sea level change during 2010, 215, and 2016. Error 13 bars show the monthly rainfall variability during this study. In December of 2015 slight 14 precipitation occurred only during the first week, however, abundant rainfall took place during 15 September-November. Sea level showed minima values during January-May and maxima during 16 August-December. Sampling campaigns were conducted during May-July (dry periods) and 17 December (wet periods).

19 Figure 3: Interpolated ${ }^{224} \mathrm{Ra}$ activity concentrations in September of 2010 along the schist and 20 karst sections. Two areas of high ${ }^{224} \mathrm{Ra}$ in coastal waters were identified in the schist section near 21 groundwater-fed Miel Creek (56 $\pm 4 \mathrm{dpm} \mathrm{m}^{-3}$ ), and the three clustered submarine springs 22 discharging from Cantarrijan Caves $\left(51 \pm 4 \mathrm{dpm} \mathrm{m}^{-3}\right)$ located in the Cantarrijan area (karst 23 section). 
25 Figure 4: Salinity anomaly map showing combined results from May, July, and December of 26 2015. Two areas of negative salinity anomalies were found in the conglomerate (salinity 27 anomaly $=-1.2$ to -1.7 ) and karst (salinity anomaly $=-0.3$ to -1.0 ) sections almost perfectly 28 aligned with their delineated extent.

Figure 5: Radon-222 distribution map based on surveys during July and December of 2015, and 31 July of 2016. Two radon peaks were in found in Maro Cliff (conglomerate section) and 32 Cantarrijan Beach (karst section) with maximum concentrations of $44 \pm 3 \times 10^{3} \mathrm{dpm} \mathrm{m}^{-3}$ and 30 $33 \pm 2 \times 10^{3} \mathrm{dpm} \mathrm{m}^{-3}$ respectively.

35 Figure 6: (a) Groundwater seepage velocity averaging results from radon mass balance and 36 seepage meters in areas of diffuse seepage (Maro Cliff and Cantarrijan Beach). Radon 37 distribution in (b) Maro Cliff (conglomerate section) and (c) Cantarrijan Beach (karst section) where cylinder symbols represent seepage meter locations and the star radon time series stations.

Figure 7: Radon fluxes result of each component of the mass balance box model during all 41 sampling campaigns in Maro Cliff (conglomerate section) and Cantarrijan Beach (karst section).

42 The largest tracer losses occurred via mixing due to the high exposure of both areas to waves and 43 currents. Greater difference in SGD- ${ }^{222} \mathrm{Rn}$ fluxes was found between wet periods (December) 44 and dry periods (July) in Cantarrijan Beach compared to Maro Cliff.

$46 \quad$ Figure 8: (a) Isotopic composition $\left(\delta^{18} \mathrm{O}, \delta^{2} \mathrm{H}\right)$ of water samples collected during all sampling 47 campaigns. Local Groundwater Line (LGL) represents the linear trend based on all groundwater 
48 samples collected in the study area. Global Meteoric Water Line (GMWL) is based on Craig, 49 (1961) and the Western Mediterranean Meteoric Water Line (WMMWL) on Gat and Garmi, 50 (1970). White color represents points of discharge in conglomerate and breccia lithology, while 51 light grey are in travertine (conglomerate section); dark grey shows points in schist (schist 52 section); and black color show locations in karstic marble (karst section). Maro Spring and Nerja 53 Cave well (not points of discharge to the sea) are represented with a black and white star 54 respectively. Water samples collected at each section (conglomerate section, schist section, ans 55 karst section) are grouped in dashed squares. (b) Isotopic composition of samples collected from 56 points of discharge from the travertine formation in the conglomerate section. The two 57 groundwater end-members (Maro Spring and irrigation waters) are circled, while diffuse seepage 58 in Maro Cliff is represented with squares.

60 Figure 9: Mixing plots of ${ }^{224} \mathrm{Ra}$ (a) and ${ }^{222} \mathrm{Rn}$ versus salinity (b) showing best fit linear and 61 exponential mixing lines, respectively, during surface water surveys along the coastline in 62 September of 2010, July and December of 2015.

64 Figure 10: Total groundwater discharge (TGD) in the study area divided in forms of discharge 65 (GS: groundwater diffuse seepage, CS: coastal springs, GC: groundwater-fed creeks, SS: 66 submarine springs), showing maximum and minimum flux during wet and dry periods.

67

68 Figure 11: Groundwater ionic relationship between $\mathrm{NO}_{3}{ }^{-}$and $\mathrm{SO}_{4}{ }^{2-}$ where groundwater samples 69 with similar composition are grouped in dashed squares. Symbols are presented as in Fig. 8 70 based on the section and lithology they are located. In the conglomerate section Maro Spring, 
71 Nerja Cave, and Maro Creek show similar $\mathrm{SO}_{4}{ }^{2-}$ concentration with low $\mathrm{NO}_{3}{ }^{-}$, while Doncellas, 72 Barranco Maro, Huerto Romero, and Maro Beach present $\mathrm{NO}_{3}{ }^{-}$contamination. Samples from the 73 schist section (Miel and Alberquillas) present a distinctive signal with low $\mathrm{NO}_{3}{ }^{-}$and $\mathrm{SO}_{4}{ }^{2-}$ 74 concentrations. Groundwater collected in Cantarrijan Beach (karst section) shows seawater 75 influence from saltwater recirculation in beach sediments. Arrows indicate the geochemical 76 change before irrigation and after fertilizers application $\left(\mathrm{NO}_{3}{ }^{-}\right)$, where Maro cliff (diffuse 77 seepage) shows mixing between both groups. 


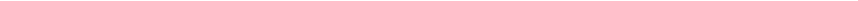




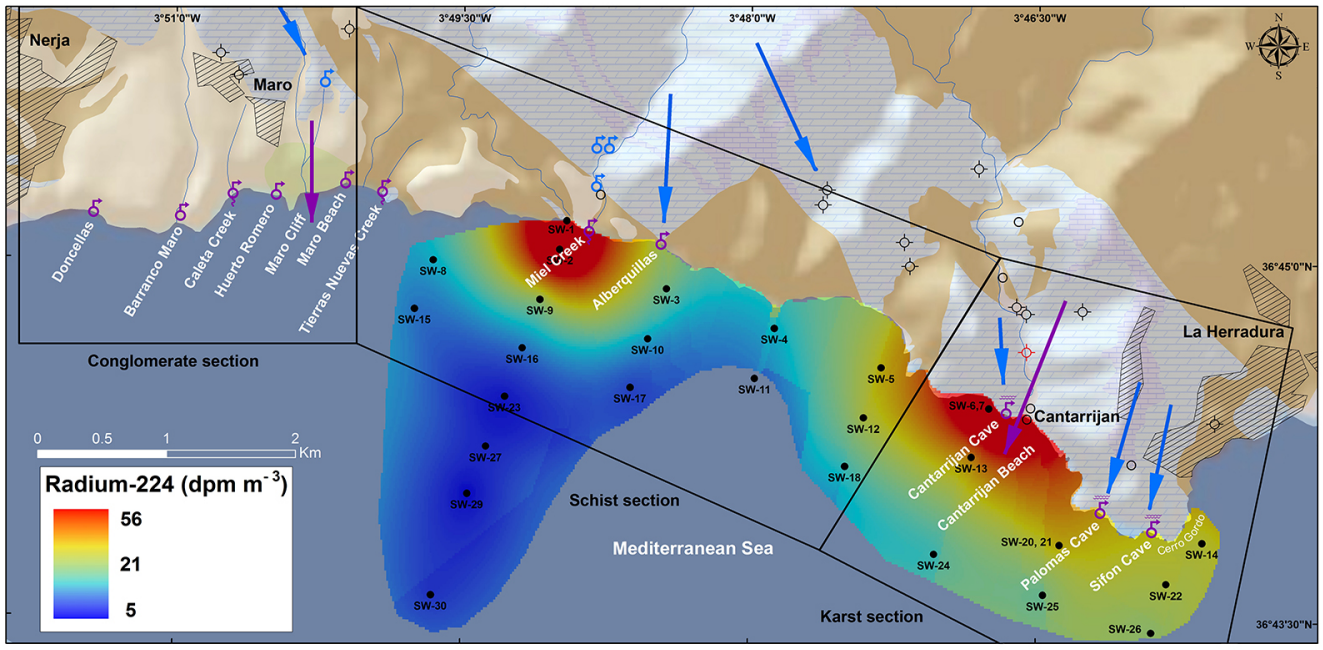




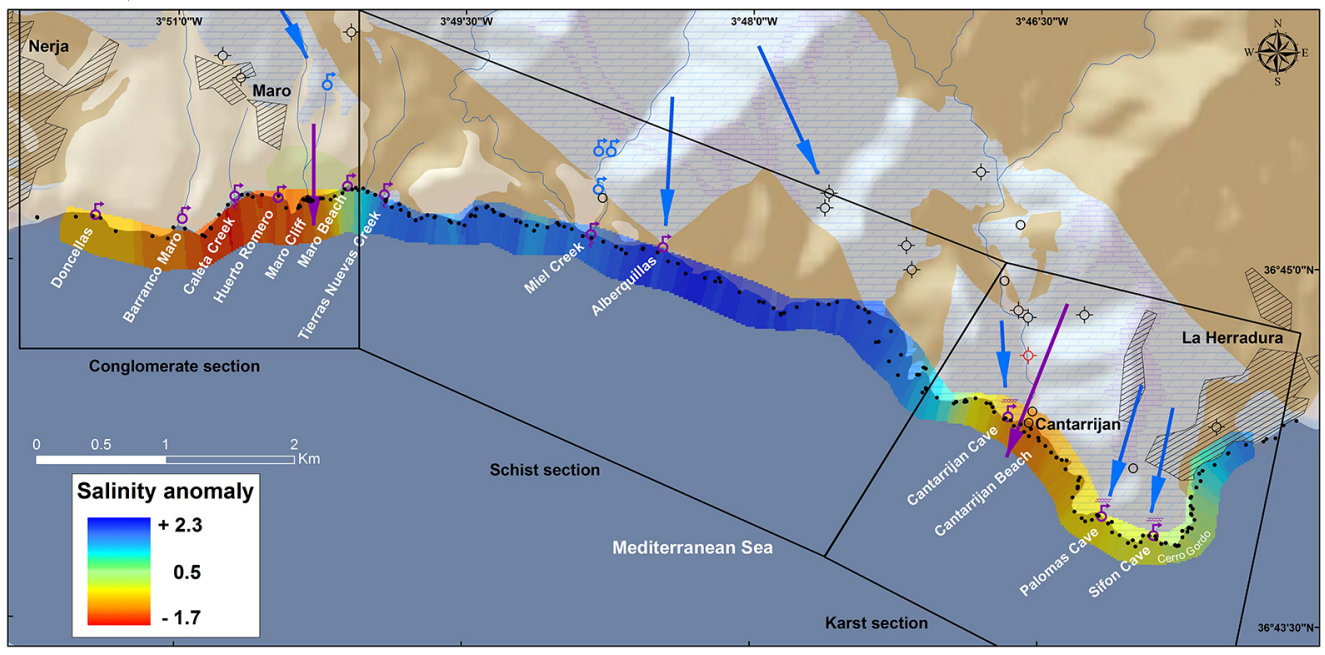




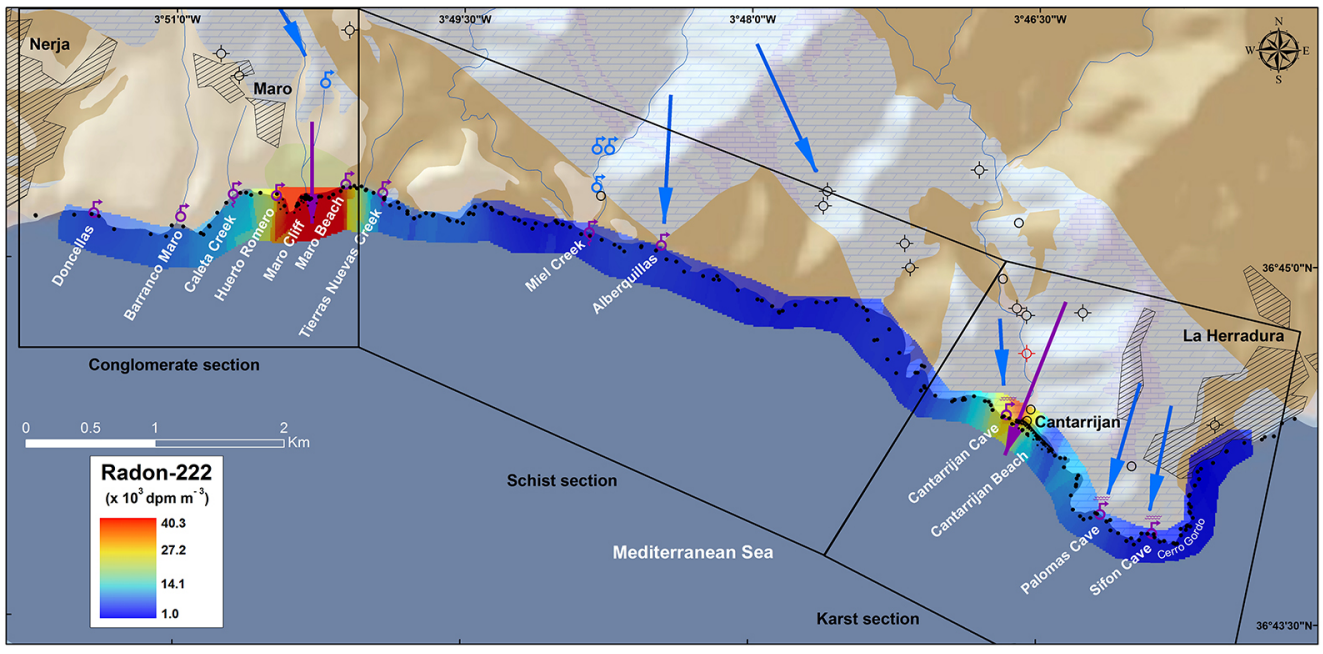




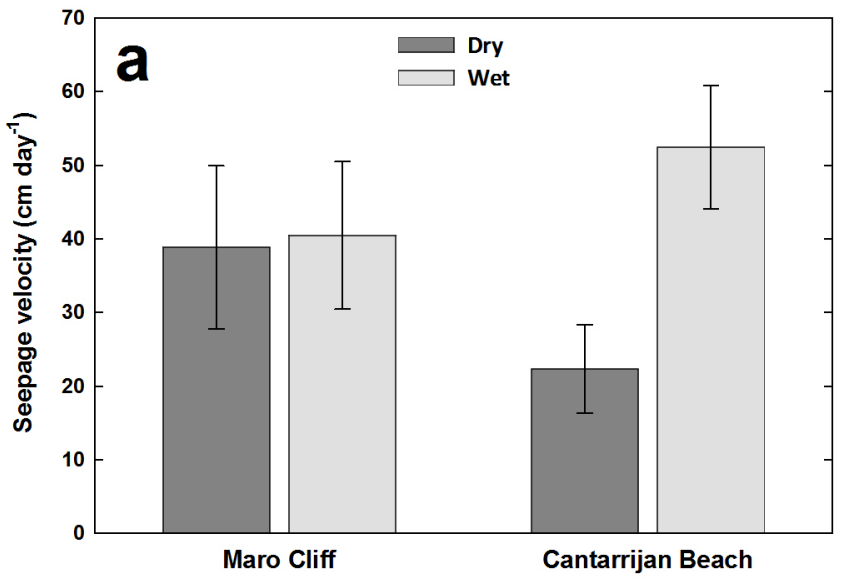




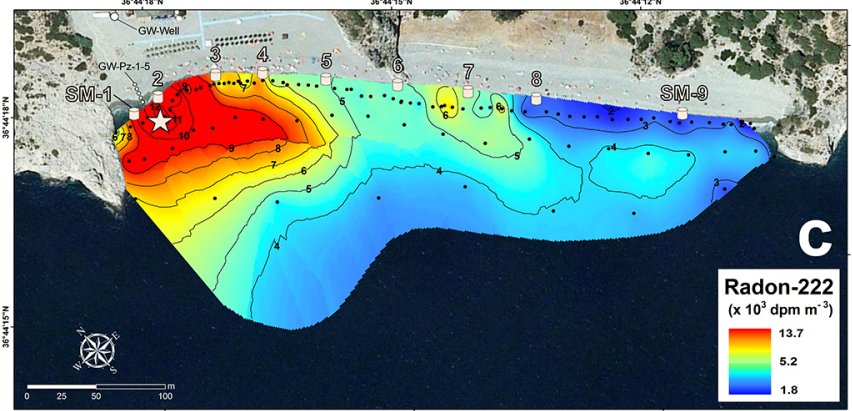




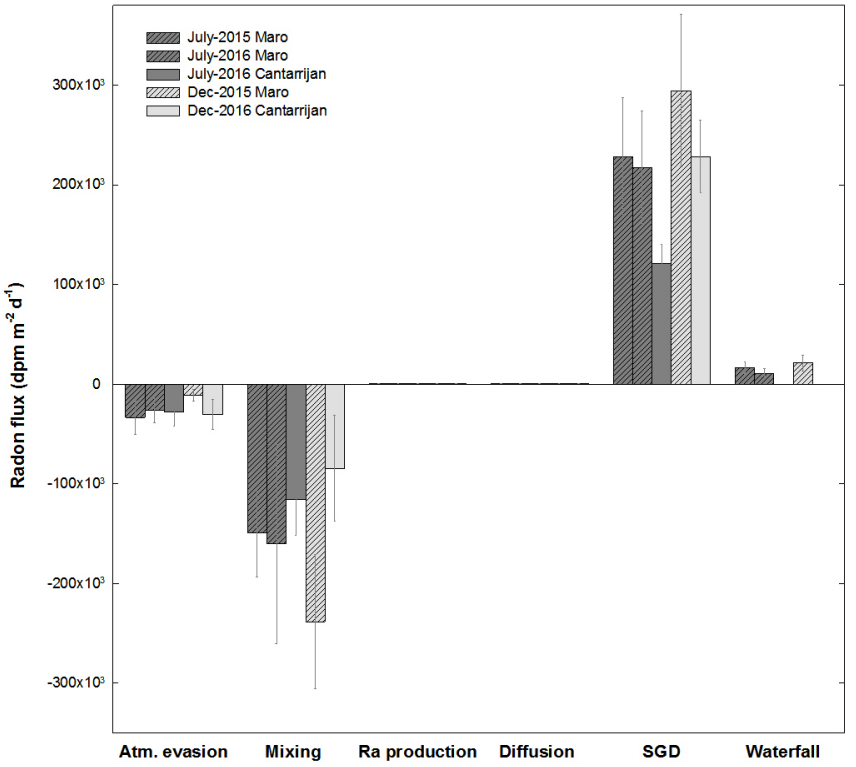




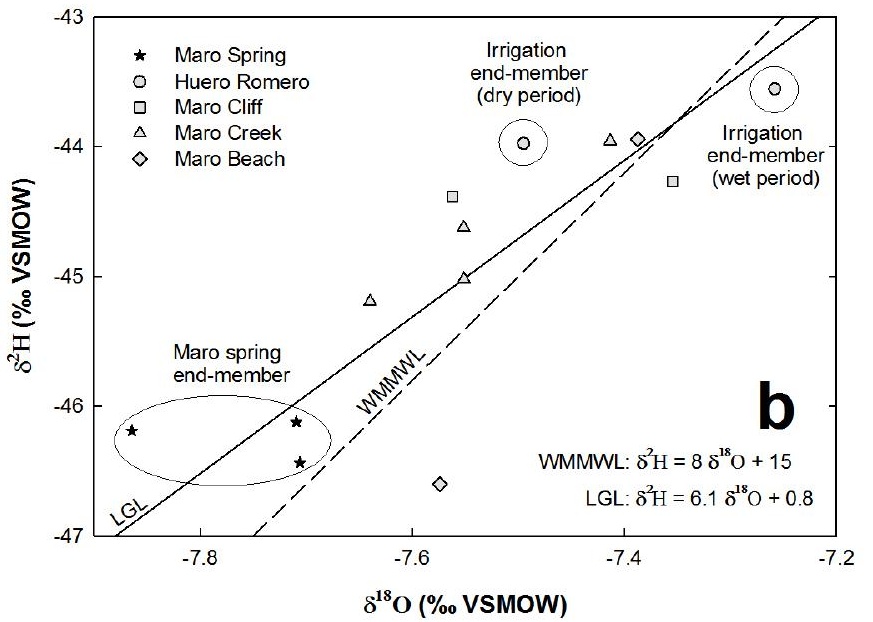




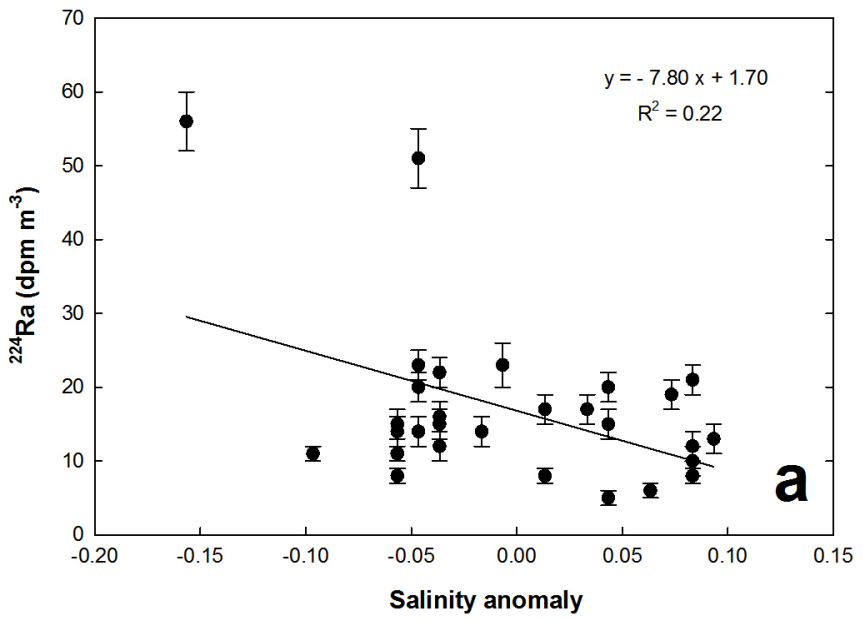




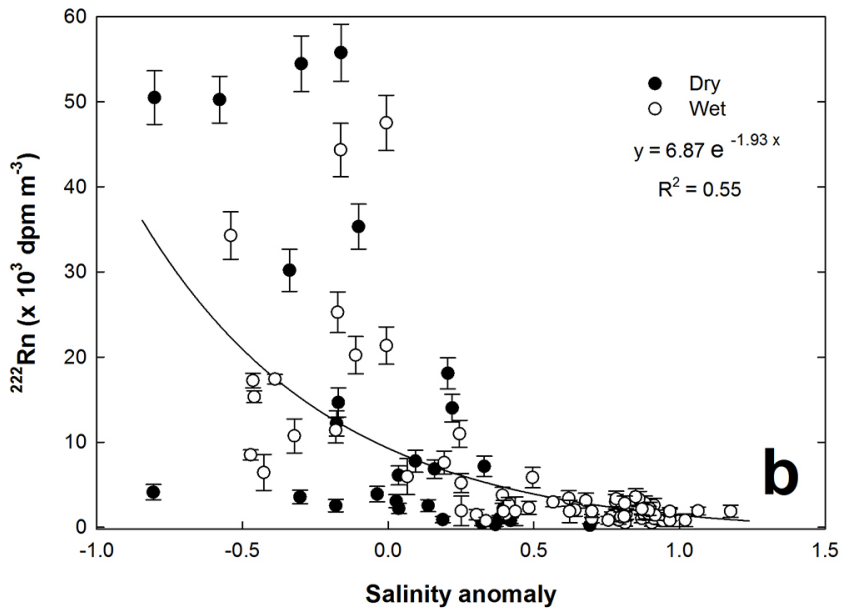




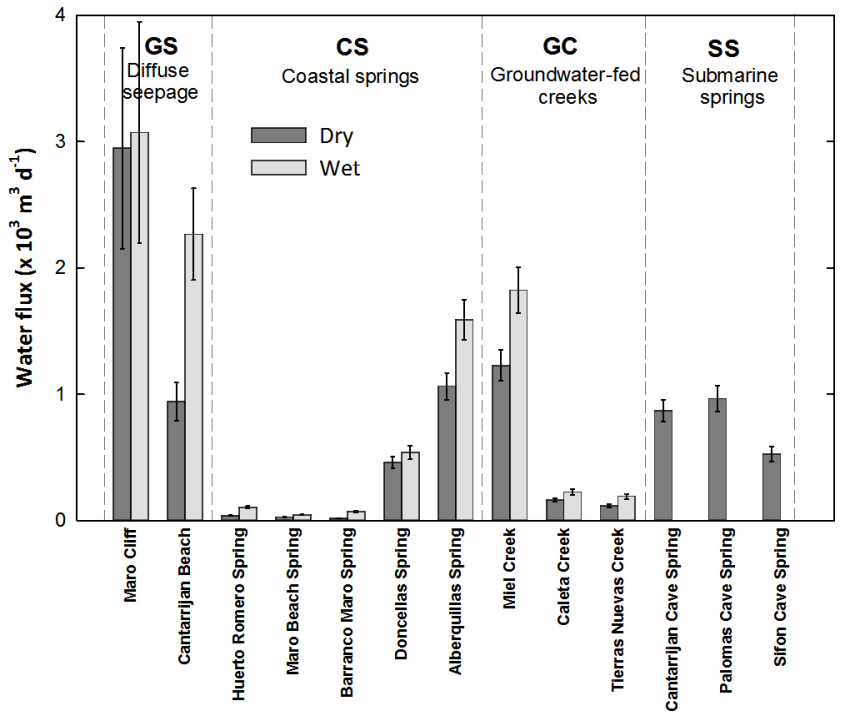


